\title{
Distinct thymocyte subsets express the vanilloid receptor VR1 that mediates capsaicin-induced apoptotic cell death
}

\author{
C Amantini ${ }^{1}$, M Mosca ${ }^{1}$, R Lucciarini ${ }^{1}$, M Perfumi ${ }^{1}$, S Morrone ${ }^{2}$, \\ M Piccoli ${ }^{2}$ and G Santoni ${ }^{\star *}, 1$ \\ 1 Department of Pharmacological Sciences and Experimental Medicine, \\ University of Camerino, Camerino, Italy \\ 2 Department of Experimental Medicine and Pathology, University 'La \\ Sapienza', Rome, Italy \\ * Corresponding author: G Santoni, Department Pharmacological Sciences and \\ Experimental Medicine, University of Camerino, Via Scalzino 3, 62032 \\ Camerino, Italy. Tel: + 390737 403312, 403319; Fax: + 390737 630618; \\ E-mail: giorgio.santoni@unicam.it
}

Received 05.2.04; revised 03.6.04; accepted 15.6.04; published online 01.10.04 Edited by B Osborne

\begin{abstract}
Herein, we provide the first evidence on the capsaicin (CPS) receptor vanilloid receptor type-1 (VR1) by rat thymocytes, and its involvement in CPS-induced apoptosis. VR1 mRNA was identified by quantitative RT-PCR in $\mathrm{CD}^{+}$thymocytes. By immunofluorescence and flow cytometry, we found that a substantial portion of $\mathrm{CD5}^{+}$thymocytes, namely $\mathrm{CD}^{+}$and double negative (DN) cell subsets, express VR1 that was present on plasma membrane on discrete spots. By Western blot, VR1 protein was identified as a single band of $95 \mathrm{kDa}$. We also described that CPS could trigger two distinct pathways of thymocyte death, namely apoptosis and necrosis depending on the dose of CPS exposure. CPS-induced apoptosis involved intracellular free calcium $\left(\mathrm{Ca}^{2+}\right)$ influx, phosphatidylserine exposure, mitochondrial permeability transmembrane pore (PTP) opening and mitochondrial transmembrane potential $\left(\Delta \Psi_{m}\right)$ dissipation leading to cytochrome $c$ release, activation of caspase-9 and -3 and oligonucleosomal DNA fragmentation. VR1 was functionally implicated in these events as they were completely abrogated by the VR1 antagonist, capsazepine (CPZ). Finally, we demonstrated that VR1 expression on distinct thymocytes was associated with the selective ability of CPS to trigger DNA fragmentation in $\mathrm{VR} 1^{+} \mathrm{CD} 4{ }^{+}$and DN thymocytes. Overall, our results suggest that the expression of VR1 on thymocytes may function as a sensor of harmful stimuli present in the thymic environment. Cell Death and Differentiation (2004) 11, 1342-1356.

doi:10.1038/sj.cdd. 4401506

Published online 1 October 2004
\end{abstract}

Keywords: apoptosis; capsaicin; vanilloid receptor type-1; thymocytes, cell death

Abbreviations: AEA, anandamide; AIF, apoptose-inducing factor; $\left[\mathrm{Ca}^{2+}\right]$, intracellular free calcium; CPS, capsaicin; $\mathrm{CPZ}$, capsazepine; CSA, cyclosporin A; DEPC, diethyl pyrocarbonate; DMSO, dimethylsulfoxide; DN, double negative; DP, double positive; EDTA, ethilenediaminetetra-acetic acid; FACS, fluorescent-activated cell sorter; FCS, fetal calf serum; FDA, fluorescent diacetate; FITC, fluorescein isothiocyanate; GAPDH, glyceraldehyde-3-phosphate dehydrogenase; HRP, horseradish peroxidase; JC-1, 5,5',6,6'-tetrachloro-1,1' ${ }^{\prime}, 3,3^{\prime}$-tetraethylbenzimidazolylcarbocyanineiodide; mAb, monoclonal antibody; MFI, mean fluorescence intensity; PBMC, peripheral blood mononuclear cells; PBS, phosphate-buffered saline; PE, phicoerythrin; $\mathrm{PI}$, propidium iodide; PMSF, phenylmethylsulfonylfluoride; PS, phosphatidylserine; PTP, permeability transmembrane pore; RAG, rabbit anti-goat; VR1, vanilloid receptor type-1; $\Delta \Psi_{\mathrm{m}}$, mitochondrial transmembrane potential

\section{Introduction}

The neurotoxin capsaicin (8-methyl- $N$-vanillyl-6-nonenamide; CPS), the pungent compound of red pepper, has been utilized as a specific tool for sensory afferent neurons, and is widely used in neurophysiological and immunopharmacological studies. ${ }^{1-6}$ Many of the acute cellular and physiologic effects associated with CPS exposure are mediated by vanilloid receptors that can act as voltage-independent channels. ${ }^{7}$ Vanilloid receptors are expressed mainly by primary sensory neurons involved in nociception and neurogenic inflammation. ${ }^{1,8}$ Vanilloid receptor 1 (VR1) was first isolated from a cDNA library from rat sensory neurons using an expressioncloning strategy. ${ }^{9}$ VR1 or TRPV1 is a nonselective cation channel structurally related to members of the transient receptor potential family of ion channels. ${ }^{10}$ The rat VR1 cDNA contains an open reading frame of 2514 nucleotides and encodes a membrane protein of 838 amino acids with a predicted molecular mass of about $95 \mathrm{kDa}^{10}$

Recent evidence indicate that VR1 expression is not restricted to primary afferent neurons and neurons of the central nervous system, ${ }^{7}$ as expression on non-neuronal cells has been also described. Indeed, VR1 mRNA and protein were found on keratinocytes, cardiomyocytes, urinary bladder and gastric mucosa epithelial cells. ${ }^{11-14}$ Moreover, functional vanilloid receptors have been found on mast cells, and mRNA for VR1 and the vanilloid receptor $5^{\prime}$ splice variant were also observed in rat peripheral blood mononuclear cells (PBMC). ${ }^{15,16}$

To date, the known activators of VR1 include a diverse set of chemical entities as well as physical stimuli such as heat. VR1 is activated by increased temperature with a threshold of about $43^{\circ} \mathrm{C}$ at $\mathrm{pH} 7.4$, indicating that it transduces painful thermal stimuli in vivo. ${ }^{9,17}$ In this regard, VR1 knocked out mice exhibit defective thermal hyperalgesia that accompanies tissue injury and inflammation. ${ }^{18}$ In addition to CPS, numerous other vanilloid and nonvanilloid compounds are VR1 
agonists. ${ }^{7}$ Indeed, lipoxygenase metabolites, particularly 12-(S)-hydroperoxyeicosatetraenoyl acid (12-(S)-HPETE), 5-(S)HETE and leukotriene $\mathrm{B}_{4}$, the endocannabinoid anandamide and its congeners, and protons are also considered endogenous modulators of VR1. ${ }^{10}$

CPS shows pharmacologically a number of effects in different cell types including cell death. ${ }^{7,19}$ CPS can cause different pathways of cell death in vivo and in vitro: apoptosis, paraptosis and necrosis depending on cell type, dose and time of CPS exposure. ${ }^{9,19-25}$ Thus, subcutaneous administration of CPS has been shown to promote DNA fragmentation, an hallmark of apoptosis in nociceptive sensory neurons. ${ }^{26}$ As shown in cultured rat dorsal root ganglion cells (DRG), CPS promotes apoptosis by increasing intracellular free $\mathrm{Ca}^{2+}\left(\left[\mathrm{Ca}^{2+}\right]_{i}\right)$, enhancing mitochondrial $\mathrm{Ca}^{2+}$ accumulation and dissipation of the inner trans-membrane potential $\left(\Delta \Psi_{\mathrm{m}}\right)$, activation of $\mathrm{Ca}^{2+}$-sensitive proteases and DNA fragmentation. ${ }^{27} \mathrm{~A}$ similar cascade of events is initiated by CPS in transformed and mitogen-activated T cells ${ }^{23}$ as well as in human and rat glioblastoma cells. ${ }^{22,28}$

However, calcium-independent induction by CPS has been also reported and attributed to CPS-induced ROS generation. ${ }^{20,21,23,29}$ Excessive $\mathrm{Ca}^{2+}$ influx triggered by vanilloid exposure can promote necrotic cell death rather than apoptosis in primary sensory neurons in vivo, ${ }^{30}$ and in vitro ${ }^{31}$ and in cell transfectants expressing VR1 vanilloid receptor. ${ }^{9,32}$

In regard to the vanilloid receptor mediating CPS-induced cell death, VR1 has been implicated in the triggering of apoptosis, paraptosis and necrosis in response to low doses of CPS in a variety of cell types..$^{9,22,32}$ However, VR1independent cell death has also been described in a number of studies using high doses of CPS and/or long-term exposure, experimental conditions that markedly affect the integrity of plasma membrane. ${ }^{19-23,25,28,29,33,34}$

We have previously reported that neonatal CPS treatment results in marked reduction of thymus weight and cellularity, impaired thymocyte proliferation in response to T-cell mitogens and apoptotic cell death. ${ }^{4,5}$ These effects are partly dependent on the ability of CPS to induce substance $P$ depletion by rat thymus. However, a direct action of CPS on thymocytes has not been explored so far nor the receptor(s) mediating these CPS-induced effects.

The aim of the present study was to investigate the expression of VR1 in rat thymocytes and its involvement in in vitro CPS-induced thymocyte apoptosis. Moreover, we examined some of the mechanisms underlying in CPS/VR1mediated apoptosis, namely calcium influx, mitochondrial transmembrane potential dissipation, cytochrome $c$ release, caspase activation and oligonucleosomal DNA fragmentation.

\section{Results}

\section{Expression of VR1 on rat thymocytes}

We have previously reported that neonatal CPS treatment induces apoptosis of rat thymocytes, ${ }^{4,6}$ but evidence on the vanilloid receptor(s) mediating these functional effects are still missing. Thus, in order to directly demonstrate VR1 mRNA expression on rat thymocytes, we initially performed real-time quantitative PCR analysis on Ficoll gradient-purified (>99\%)
$\mathrm{CD}^{+}$thymus cells. Our results indicate that VR1 mRNA expression is lower (2.5-fold less) in rat thymocytes as compared to the brain tissue used as positive control (Figure 1a), as shown by quantitative analysis and the finding of a PCR product of expected size (62 bp) (Figure $1 \mathrm{~b}$ ).

The expression of VR1 on rat thymocytes was also assessed at protein level. Western blot analysis of cell lysates from thymocytes revealed a band with apparent MW of $95 \mathrm{kDa}$ (Figure 1c), likely corresponding to the vanilloid receptor VR1, as a similar band was also evident in lysates from rat brain tissue used as positive control. ${ }^{7}$ No reactivity was observed with normal goat serum used as negative control (data not shown). Immunofluorescence and fluorescent-activated cell sorter (FACS) analysis indicates that a substantial portion of
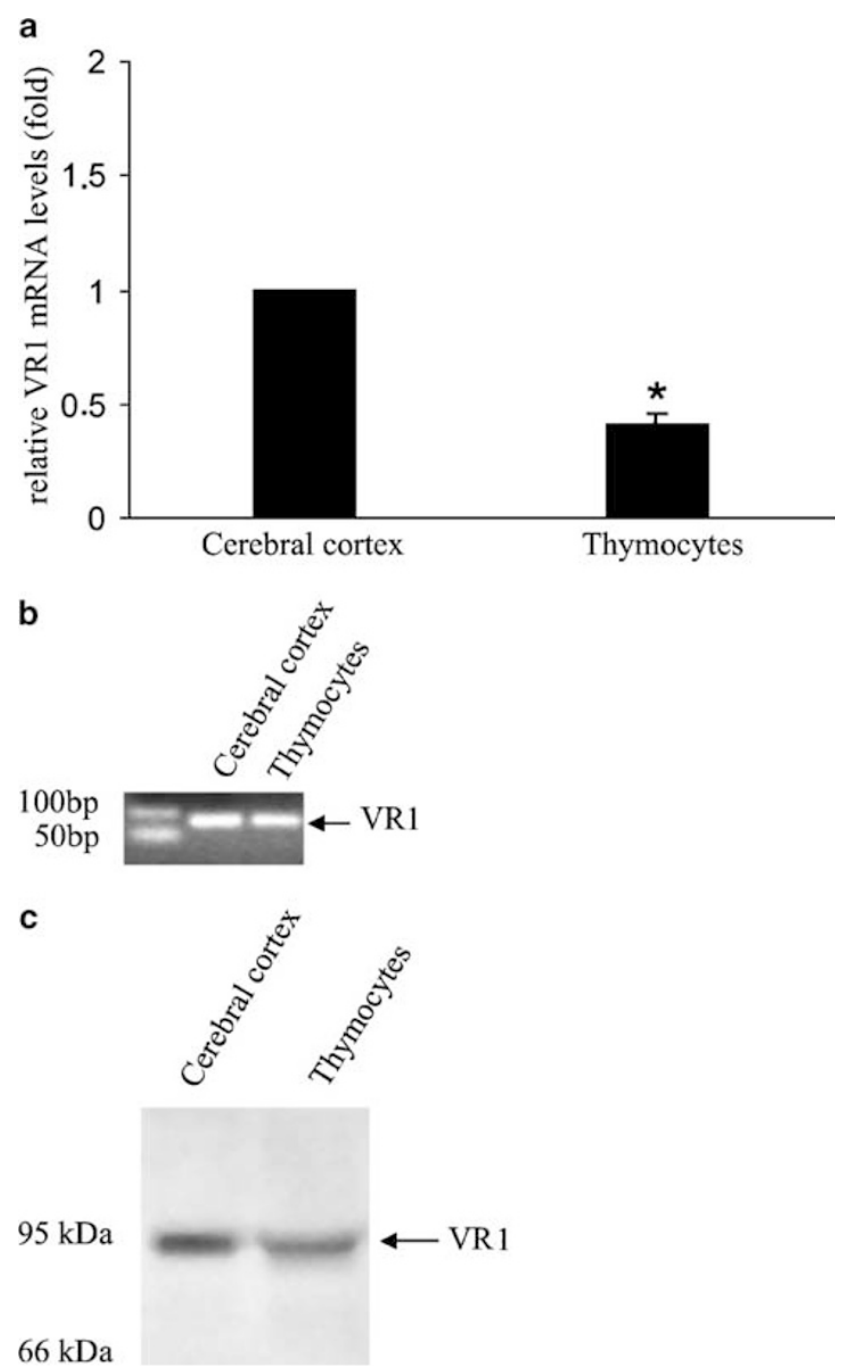

Figure 1 Expression of VR1 on rat thymocytes. (a) VR1 mRNA levels on rat thymocytes (>99\% $\mathrm{CD}^{+}$cells) and cerebral cortex were evaluated by quantitative RT-PCR assay in triplicate, and the results (mean \pm S.D.) are normalized for GAPDH expression. Data shown are representative of three separate experiments. The statistical significance of the fold decrease of baseline control levels (rat cerebral cortex). (b) PCR products from rat thymocytes and cerebral cortex. (c) Lysates from rat thymocytes and cerebral cortex were separated on 7\% SDS-PAGE and probed with a goat anti-VR1 polyclonal Ab. Sizes are shown in $\mathrm{kDa}$, and arrowhead indicates the band corresponding to VR1. The data shown are representative of three separate experiments 


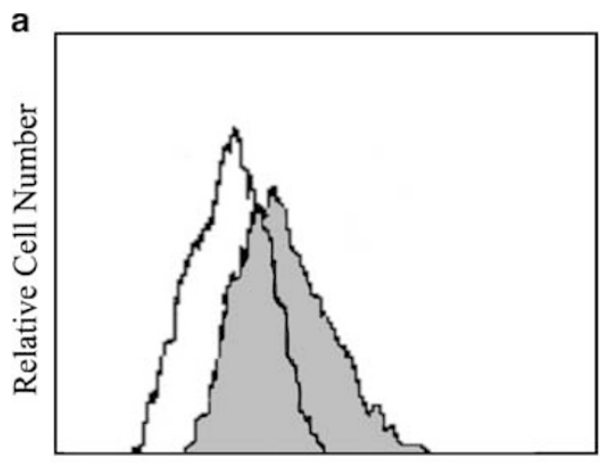

Fluorescence Intensity

b
RAG

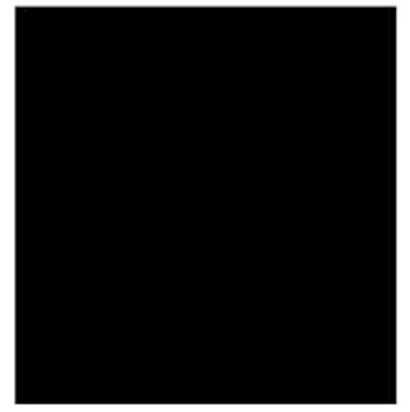

anti-VR1

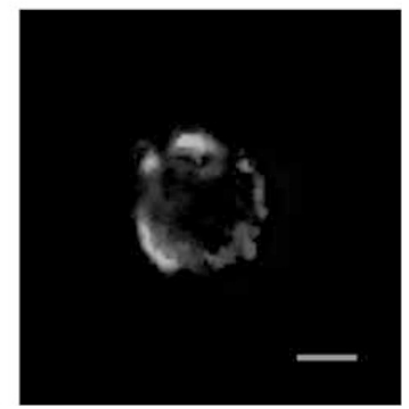

Figure 2 Expression of VR1 protein by rat thymocytes. (a) The expression of VR1 on thymocytes ( $>99 \% \mathrm{CD}^{+}$cells) was evaluated by immunofluorescence and FACS analysis using a goat anti-VR1 $\left(\mathrm{NH}_{2}\right.$ terminal peptide) polyclonal $\mathrm{Ab}$. FITC-conjugated RAG was used as secondary $A b$. The data shown are representative of three separate experiments and are expressed as mean fluorescence intensity (MFI); RAG MFI $=6.3$; anti-VR1 $=68.2$. White area indicates negative control. (b) Immunocytochemical localization of VR1 on rat thymocytes as evaluated by confocal microscopy. Goat anti-VR1 polyclonal Ab and FITC-conjugated RAG were used as primary and secondary Ab, respectively. Each image is the sum of one of three single optical sections taken at $1-\mu \mathrm{M}$ intervals. Bars $=5 \mu \mathrm{M}$. Data shown are representative of three separate experiments

thymocytes express high levels of VR1 protein (Figure 2a), and confocal microscopy analysis shows that VR1 is present in discrete spots on thymocyte plasma membrane (Figure 2b).

Taken together, these results first demonstrate the expression of the vanilloid receptor VR1 on rat CD5 ${ }^{+}$thymocytes both at mRNA and protein levels.

\section{CPS triggers in a dose-dependent manner distinct pathways of thymocyte cell death}

Recent findings indicate that CPS in vitro can induce distinct pathways of cell death in different cell types depending on dose and time exposure. ${ }^{19}$ We investigated whether in vitro treatment of thymocytes with CPS could affect thymus cell viability and induce necrotic and/or apoptotic cell death.

We initially evaluated CPS-induced changes in thymocyte viability by flow cytometry, determining the relative numbers of living cells by fluorescent diacetate (FDA).
We found that the percentage of dead thymocytes increases with the increase of CPS dose from $8.5 \%$ in untreated thymocytes, to $34.5,94$ and $98 \%$ in thymocytes treated with 5,10 or $25 \mu \mathrm{M}$ of CPS, respectively (Figure $3 a$ ), indicating that CPS markedly affects thymocyte viability in a dose-dependent manner, with higher doses mediating massive cytotoxic effects.

DNA fragmentation during apoptosis leads to extensive loss of DNA content resulting in a characteristic internucleosomal DNA ladder evidenced by agarose gel electrophoresis, and a distinct sub-Go/G1 peak detected by propidium iodide (PI) staining and flow cytometry.

FACS analysis of stained nuclei from untreated thymocytes shows the existence of two peaks, namely a narrow fluorescent peak corresponding to diploid DNA content and a broader hypodiploid peak that corresponds to apoptotic nuclei.

Thymocyte treatment with CPS $(5,10$ and $25 \mu \mathrm{M})$ resulted in a dose-dependent increase of hypodiploid DNA content from $10.1 \%$ (untreated thymocytes) to $36 \%$ (CPS $5 \mu \mathrm{M}$ ), $79 \%$ (CPS $10 \mu \mathrm{M}$ ) and 93\% (CPS $25 \mu \mathrm{M}$ ) (Figure 3b). The staining pattern of $\mathrm{PI}$ in $5 \mu \mathrm{M}$ CPS-treated thymocytes showed DNA degradation with a broad peak indicative of hypodiploid DNA and a narrow peak of intact DNA; at higher doses, (10 and $25 \mu \mathrm{M})$, CPS induced massive DNA degradation accompanied by loss of nondegraded DNA.

In accordance with cytofluorimetric analysis, agarose gel electrophoresis evidenced thymocyte necrosis or apoptosis depending on the CPS concentration used. At low concentration $(5 \mu \mathrm{M})$, CPS induced apoptosis as evidenced by a characteristic ladder pattern of DNA fragments, whereas at higher concentration $(25 \mu \mathrm{M})$, a diffuse smearing of degraded DNA was observed, strongly suggestive of necrotic cell death (Figure 3c, left panel).

Time-course analysis of CPS $(5 \mu \mathrm{M})$-induced apoptosis evidenced DNA laddering at $4 \mathrm{~h}$ after treatment, and increased at later times (6-8h) (Figure $3 \mathrm{c}$ middle panel).

We also evaluated the involvement of VR1 in the CPSinduced oligonucleosomal DNA fragmentation by the use of the specific VR1 antagonist, ${ }^{35}$ capsazepine (CPZ), (Figure 3c right panel). Pretreatment of thymocytes with CPS plus CPZ (1:2 agonist/antagonist ratio), completely inhibited CPSinduced DNA fragmentation. No cell death was observed when thymocytes were incubated at the same times with the CPS or CPZ vehicle alone (data not shown).

Overall, these results indicate that in vitro CPS treatment triggers two distinct pathways of cell death in rat thymocytes: necrosis is induced by higher concentrations of CPS, whereas VR1-dependent apoptosis is observed at low dose.

\section{CPS triggers a VR1-dependent extracellular $\mathrm{Ca}^{2+}$ influx}

Stimulation of endogenous VR1 on different neuronal ${ }^{27,35,36}$ and non neuronal cell types, ${ }^{14,15,37}$ by CPS results in dosedependent influx of $\mathrm{Ca}^{2+}$, which is inhibited by the VR1 antagonist, CPZ.

Thus, to characterize calcium transport through the VR1 channel, we followed the CPS-induced $\mathrm{Ca}^{2+}$ influx by 

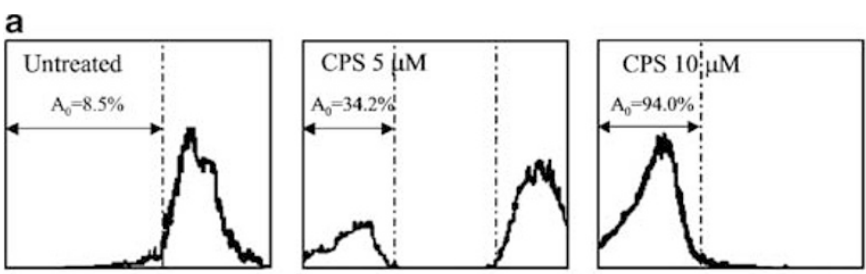

FDA

b
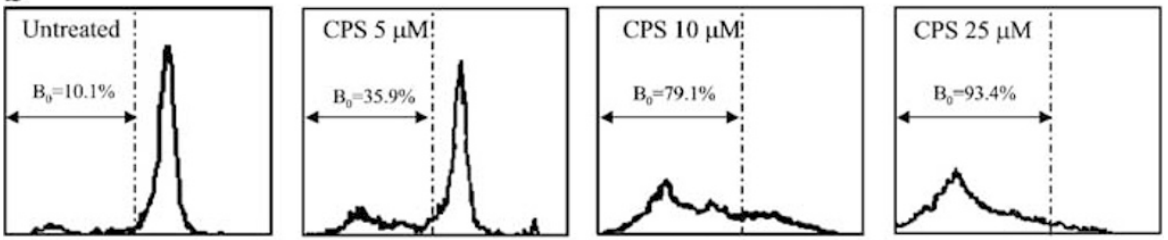

PI

C
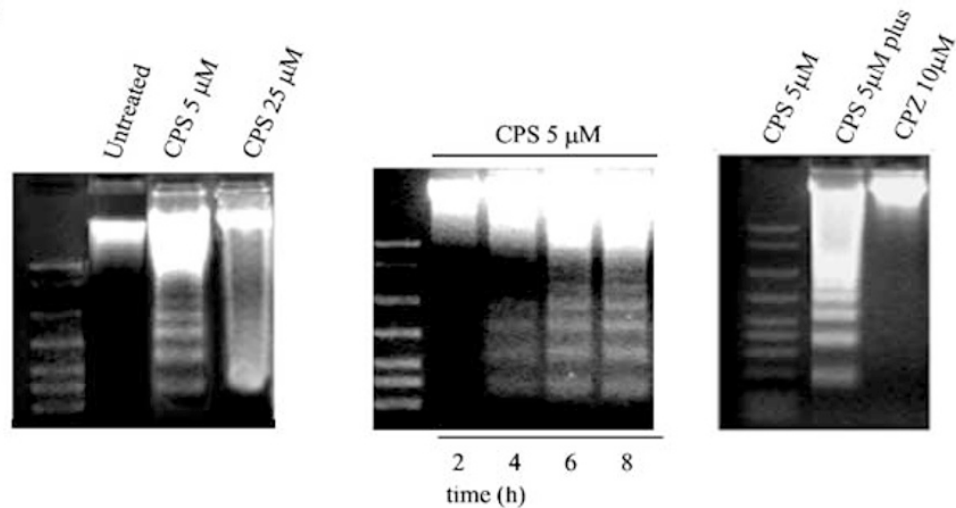

Figure 3 CPS triggers in a dose-dependent manner distinct pathways of thymocyte cell death. (a) Rat thymocytes ( $>99 \%$ CD5 ${ }^{+}$cells) were treated with 5,10 or $25 \mu \mathrm{M} \mathrm{CPS}$ for $8 \mathrm{~h}$, and the relative numbers of FDA-positive thymocytes were evaluated by flow cytometric analysis. Panels show the distribution of green fluorescence; the region on the left of FITC peak designed as Ao represents cells undergoing cell death. Data shown are representative of three separate experiments. (b) Rat thymocytes ( $>99 \% \mathrm{CD}^{+}$cells) were treated with the indicated concentrations of CPS for $8 \mathrm{~h}$, and cell cycle was analyzed by PI staining. $\mathrm{B}_{0}$ indicates the region on the left of Go/G1 peak that corresponds to the percentage of hypodiploid thymocytes. Data shown are representative of three separate experiments. (c) (Left panel) Doseresponse analysis of DNA fragmentation from untreated, or 5,10 or $25 \mu \mathrm{M}$ CPS-treated thymocytes for $8 \mathrm{~h}$ was performed by agarose gel (1.7\%) electrophoresis. Middle panel: Time-course analysis of DNA fragmentation from $5 \mu \mathrm{M}$ CPS-treated thymocytes was performed at different times $(2,4,6$ or $8 \mathrm{~h})$ after treatment was performed as above described. Right panel: Analysis of DNA fragmentation from $(5 \mu \mathrm{M})$ CPS- or CPS plus CPZ-treated (1:2 agonist/antagonist ratio) thymocytes was evaluated as described above. Data shown are representative of three separate experiments

cytofluorimetric analysis in thymocytes loaded with FLUO 3 fluorescent dye which once inside the cells captures $\mathrm{Ca}^{2+}$ with high affinity and becomes more fluorescent. CPS $(5 \mu \mathrm{M})$ stimulation of thymocytes in $\mathrm{Ca}^{2+}$-containing medium induced a rise of $\left[\mathrm{Ca}^{2+}\right]_{i}$ from 100 to $350 \mathrm{nM}$ (3.7-fold increase) (Figure $4 \mathrm{a})$. The kinetics of $\left[\mathrm{Ca}^{2+}\right]_{\mathrm{i}}$ mobilization shows that CPS induces a delayed (25 min after CPS treatment) response which peaked at $45 \mathrm{~min}$ and remained sustained at later time points.

We also examined the source of calcium responsible for these changes by stimulating the thymocytes with the same dose of CPS in the presence of the extracellular chelator, ethilenediaminetetra-acetic acid (EDTA) ( $5 \mathrm{mM}$ ) (nominally $\mathrm{Ca}^{2+}$-free medium), and measuring the $\left[\mathrm{Ca}^{2+}\right]_{i}$ levels as above described. Under these conditions, the ability of CPS to induce $\left[\mathrm{Ca}^{2+}\right]_{i}$ mobilization was completely blocked. CPSinduced $\mathrm{Ca}^{2+}$ response was mediated by VR1 as shown by its abrogation by the simultaneous treatment with the CPZ antagonist (Figure 4b).
Intracellular calcium flux plays a major role in many pathways leading to apoptotic cell death in several cell types, ${ }^{19,38}$ and elevation of $\left[\mathrm{Ca}^{2+}\right]_{\mathrm{i}}$ has been implicated in thymocyte apoptosis induced by anti-CD3 antibody, glucocorticoids and $\mathrm{Ca}^{2+}$ ionophore. ${ }^{39,40}$ However, CPS-induced $\mathrm{Ca}^{2+}$ influx has not been associated with induction of apoptosis in mitogen-activated or transformed T cells. ${ }^{23}$

Thus, to gain insight into the pathways that connect calcium influx with CPS-induced apoptotic cell death of rat thymocytes, we determined the requirement of extracellular calcium in CPS-triggered oligonucleosomal DNA fragmentation. As shown by agarose gel electrophoresis, CPS-induced internucleosomal DNA laddering was completely inhibited in the presence of EDTA (Figure 4c).

Taken together, these results indicate that CPS induced ligand-gated $\mathrm{Ca}^{2+}$ influx in rat thymocytes is mediated by VR1, and this event is required for CPS-induced DNA fragmentation. 

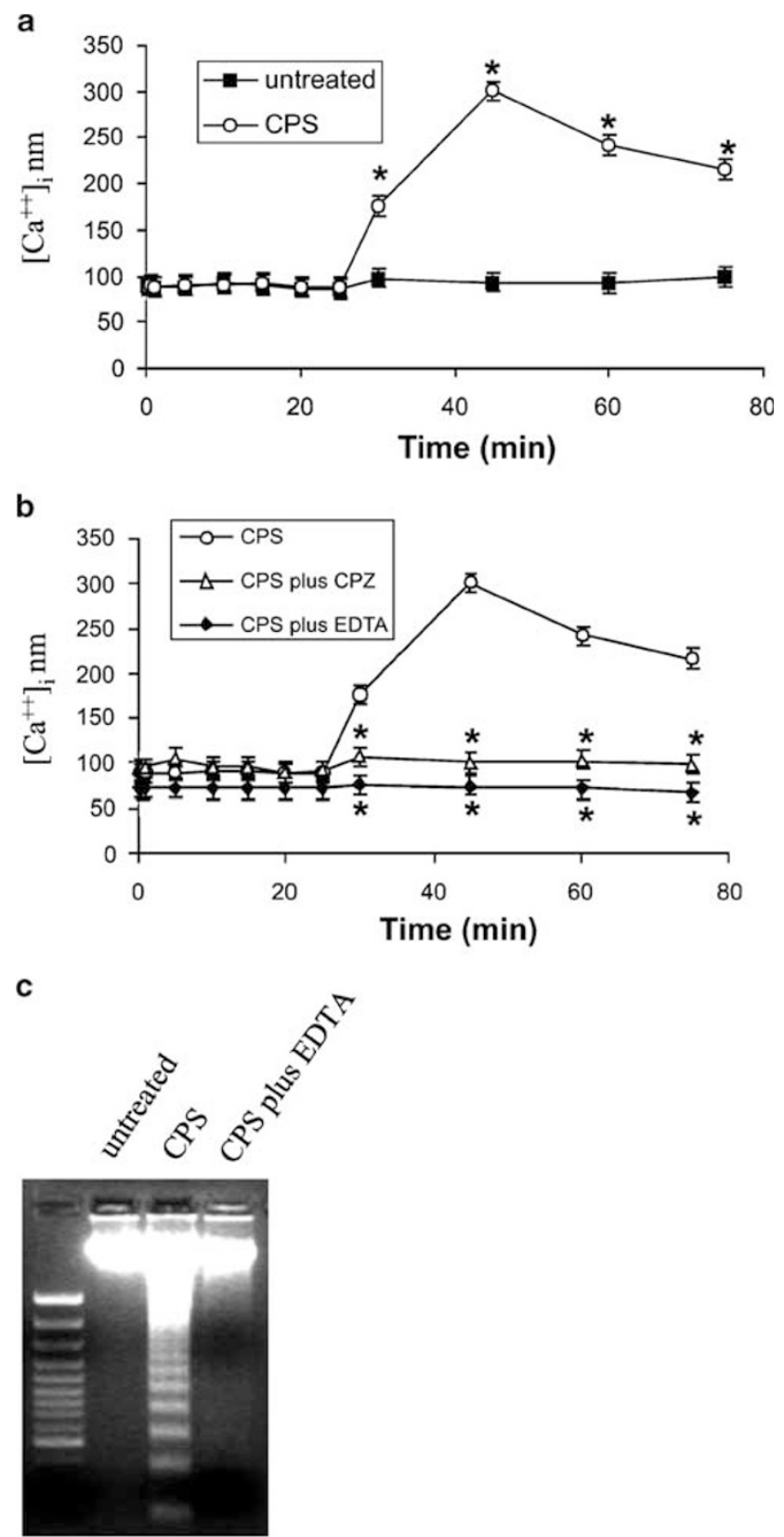

Figure 4 VR1 triggering on rat thymocytes by CPS induces calcium influx $\left(\left[\mathrm{Ca}^{2+}\right]_{\mathrm{i}}\right)$ and $\mathrm{Ca}^{2+}$-dependent oligonucleosomal DNA fragmentation. (a) Time course of $\left[\mathrm{Ca}^{++}\right]_{\mathrm{i}}$ rise in FLUO 3-loaded untreated or CPS $(5 \mu \mathrm{M})$-treated thymocytes $\left(>99 \% \mathrm{CD}^{+}\right.$cells) was evaluated at different times by cytofluorimetric and FACS analysis. Data shown are the mean + S.D. of three separate experiments. Statistical analysis was determined by comparing untreated with CPS-treated thymocytes; ${ }^{*} P<0.01$ determined by Student's $t$ test. (b) Time course of $\left[\mathrm{Ca}^{++}\right]_{\mathrm{i}}$ rise in FLUO 3 -loaded $(5 \mu \mathrm{M})$ CPS-, CPS plus CPZ (1:2 agonist/antagonist ratio), or CPS plus $(5 \mathrm{mM})$ EDTA (calcium-free medium)-treated thymocytes was evaluated by cytofluorimetric and FACS analysis as described above. Data shown are the mean \pm S.D. of three separate experiments. Statistical analysis was determined by comparing CPS- with CPS plus CPZ- or CPS plus EDTA-treated thymocytes; ${ }^{*} P<0.01$ determined by Student's $t$-test. (c) Oligonucleosomal DNA fragmentation of untreated or $(5 \mu \mathrm{M})$ CPS-treated thymocytes in the presence or absence of EDTA $(5 \mathrm{mM})$ was evaluated by agarose gel electrophoresis. Data shown are representative of three separate experiments

\section{CPS treatment induces VR1-dependent phosphatidylserine (PS) exposure on VR1 ${ }^{+}$thymocytes}

A characteristic feature of apoptotic cell death is the loss of phospholipid asymmetry and expression of PS on the outer layer of the plasma membrane. Once the functional expression of the VR1 on thymocytes was observed, we analyzed whether the CPS-induced opening of calcium channels could induce externalization of PS residues from the inner to the outer leaflet of the plasma membrane in these cells. To this end we analyzed annexin V binding on VR1 ${ }^{+}$thymocytes by two-color flow cytometric analysis. As shown in Figure 5a, treatment with CPS induces an early (30-min) translocation of PS in about $13 \%$ of VR1 ${ }^{+}$thymocytes. PS exposure on VR1 ${ }^{+}$ thymocytes increased in a time-dependent manner and about $30 \%$ of VR1 ${ }^{+}$thymocytes displayed PS on the outer leaflet of the plasma membrane at $1 \mathrm{~h}$ after treatment with CPS. The percentage of Annexin $\mathrm{V}^{+} \mathrm{VR} 1^{+}$thymocytes declined at $2 \mathrm{~h}$ (to about 10\%), and progressively returned to baseline levels at $8 \mathrm{~h}$ (Figure 5a). CPS-induced PS exposure on VR1 ${ }^{+}$
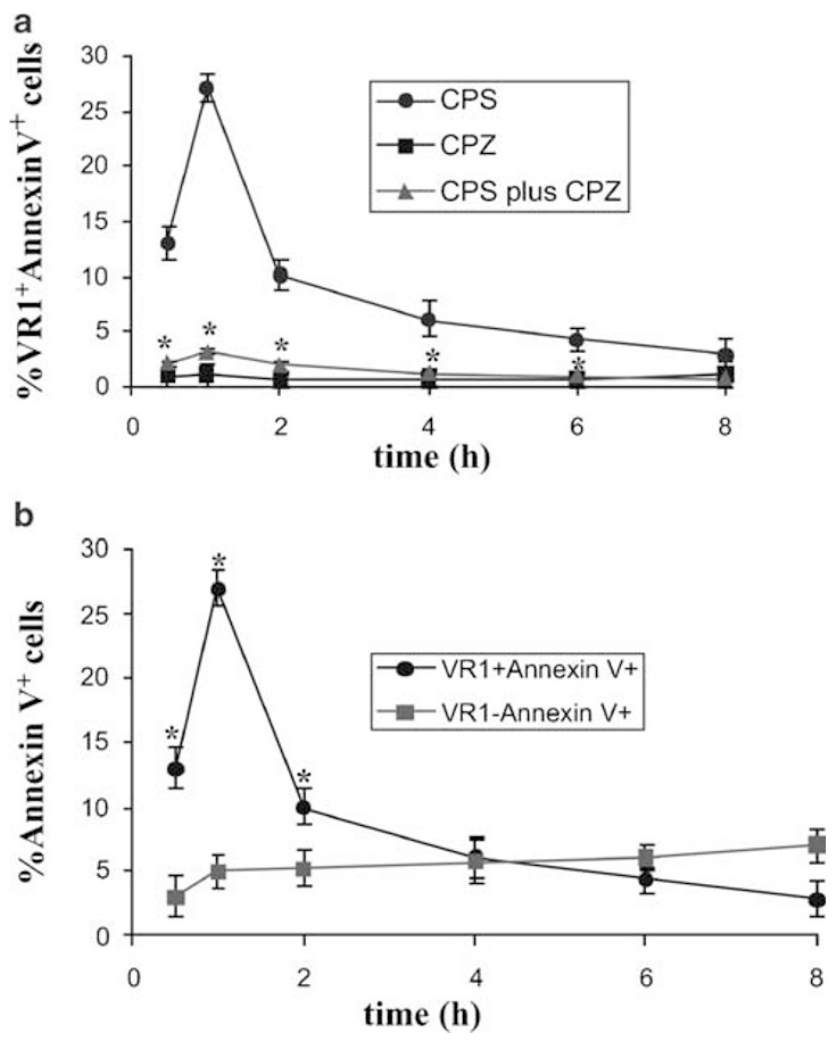

Figure 5 CPS treatment modulates VR1 expression and induces PS exposure in rat thymocytes. (a) The percentage of $\mathrm{VR} 1{ }^{+}$Annexin $\mathrm{V}^{+} \mathrm{CD} 5^{+}$thymocytes treated at different times $(0.5,1,2,4,6$ or $8 \mathrm{~h})$ with $(5 \mu \mathrm{M}) \mathrm{CPS}(10 \mu \mathrm{M}) \mathrm{CPZ}$ or CPS plus CPZ (1:2 agonist/antagonist ratio) was evaluated by double immunofluorescence and FACS analysis. Data are the mean \pm S.D. of three different experiments. Statistical analysis was determined by comparing CPSwith $\mathrm{CPZ}$ or CPS plus CPZ-treated thymocytes; ${ }^{*} P<0.01$ determined by Student's $t$-test. (b) The expression of Annexin V on VR1 ${ }^{+}$or VR1 ${ }^{-}$thymocytes treated at different times as above described, with $(5 \mu \mathrm{M})$ CPS was evaluated by immunofluorescence and FACS analysis. Data are the mean \pm S.D. of three different experiments. Statistical analysis was determined by comparing Annexin $\mathrm{V}^{+} \mathrm{VR} 1{ }^{+}$with $\mathrm{VR} 1{ }^{-}$thymocytes upon CPS treatment; ${ }^{*} P<0.01$ determined by Student's $t$-test 
thymocytes was mediated by VR1 as it was completely reverted by $\mathrm{CPZ}$ antagonist; $\mathrm{CPZ}$ alone did not affect PS expression on thymocytes (Figure 5a).

We also examined the ability of CPS to induce PS exposure in the $\mathrm{VR}^{-}$thymocytes and we found no increase in PS expression at each experimental time points tested (Figure 5b).

\section{Cyclosporin A (CSA) prevents CPS-induced VR1-dependent PS exposure}

CSA has been shown to inhibit apoptotic cell death induced by mitochondrial damage by preventing the opening of the permeability transition pore (PTP). ${ }^{41}$ Moreover, CSA inhibits CPS-induced apoptosis in human lymphoblastoid cells by blocking the activation of the calcium- and calmodulindependent serine and threonine protein phosphatase calcineurin. ${ }^{21}$

Thus, in order to investigate the contribution of mitochondria to PS exposure, we analyzed the effect of CSA on CPSinduced Annexin $\mathrm{V}$ binding on thymocytes by biparametric cytofluorimetric analysis of Annexin V-FITC fluorescence intensity versus forward light scatter values. CSA markedly prevented CPS-induced PS exposure on the outer leaflet of the plasma membrane of thymocytes showing a timedependent cell shrinkage (measured by a decrease in forward scatter) (Figure 6), suggesting an involvement of mitochondria in CPS-induced thymocyte apoptosis.

\section{CPS triggers VR1-dependent mitochondrial $\Delta \Psi_{\mathrm{m}}$ dissipation}

To further investigate the role of mitochondria in CPS-induced apoptotic cell death, we labelled thymocytes treated with CPS at different times $(2,4,6$ or $8 \mathrm{~h})$ with $\mathrm{JC}-1\left(5,5^{\prime}, 6,6^{\prime}\right.$ - tetrachloro-1, 1', 3,3'-tetraethylbenzimidazolylcarbocyanineiodide $)^{42}$ and measured $\Delta \Psi_{\mathrm{m}}$ by two-color flow cytometry. Treatment with CPS induced a time-dependent decrease of red fluorescence and a concomitant increase of green fluorescence intensity (depolarization) in rat thymocytes. CPS-induced $\Delta \Psi_{\mathrm{m}}$ dissipation was evident $2 \mathrm{~h}$ after vanilloid treatment in about $15 \%$ of thymocytes, increased at 4 and $6 \mathrm{~h}$ with approximatively 20 and $24 \%$ of thymocytes showing a drop of $\Delta \Psi_{\mathrm{m}}$, respectively, and was maximal after $8 \mathrm{~h}$ with $29 \%$ of thymocytes showing $\Delta \Psi_{\mathrm{m}}$ dissipation (Figure $7 \mathrm{a}$ ). Carbonyl cyanide chlorophenylhydrazone (CCCP) protonophore, a mitochondrial uncoupler that collapses $\Delta \Psi_{\mathrm{m}}$ was used as positive control (data not shown).

The involvement of VR1 in the CPS-induced $\Delta \Psi_{\mathrm{m}}$ dissipation was evaluated by treating thymocytes with $C P S$ plus $C P Z$ (1:2 agonist/antagonist ratio). CPZ completely reverted the CPS-induced mitochondrial depolarization at each time point; CPZ alone did not affect the mitochondrial integrity of thymocytes (Figure 7b).

Consistent with the annexin $\mathrm{V}$ binding results (see above), depletion of extracellular calcium by EDTA, or addition of the PTP inhibitor CSA, blocked the ability of CPS to dissipate $\Delta \Psi_{\mathrm{m}}$ (Figure 7c).

Overall, these results suggest that CPS-induced VR1mediated dissipation of $\Delta \Psi_{\mathrm{m}}$ involves mitochondrial calcium uptake and PTP opening induced by calcium overload.

\section{CPS treatment induces VR1-dependent mitochondria release of cytochrome $c$}

Massive calcium uptake induces collapse of the mitochondrial membrane potential, increase of the mitochondrial permeability and the release of proapoptotic factors such as cytocrome $c$ and/or the apoptosis inducer factor (AIF). ${ }^{41}$

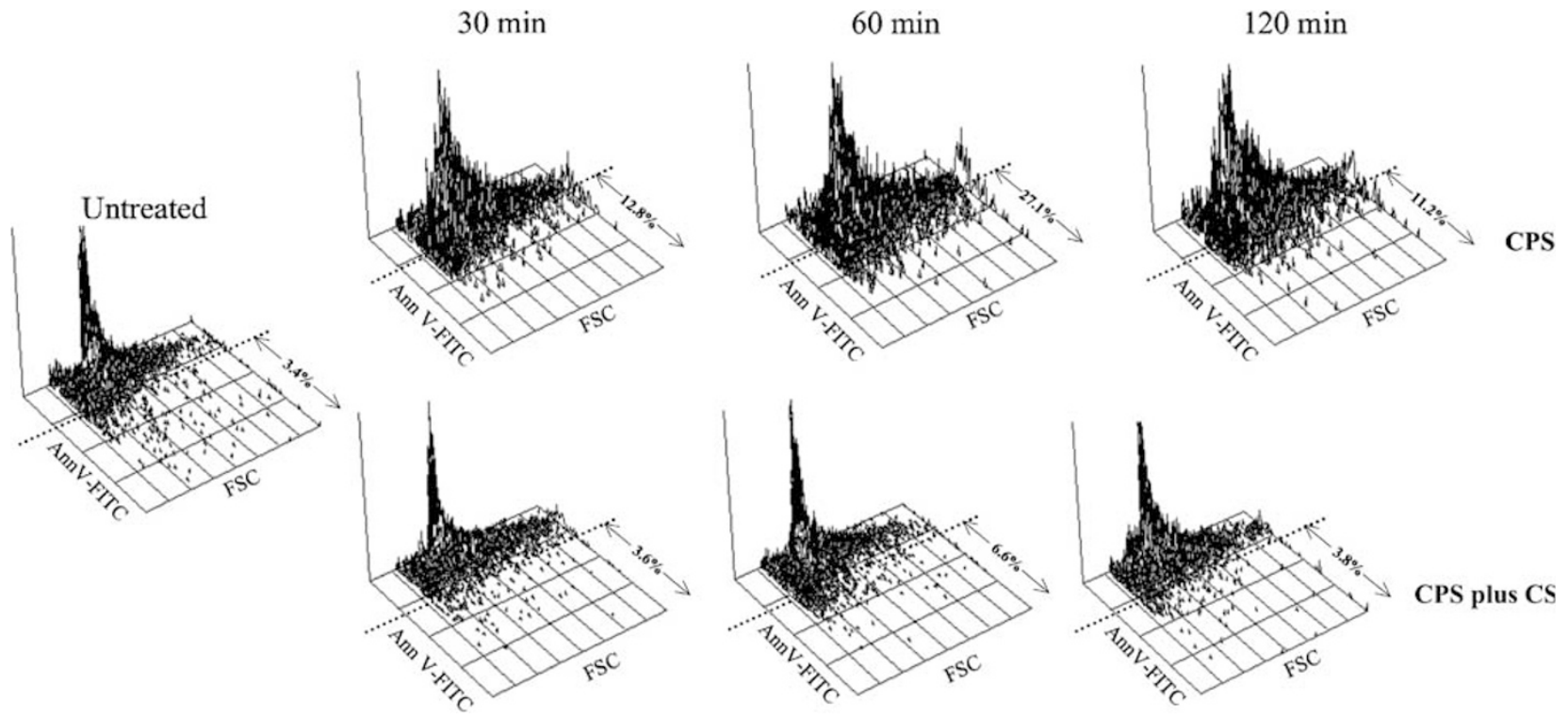

Figure 6 CPS-induced PS exposure on rat thymocytes involves mitochondrial PTP opening. Time course of PS exposure in untreated, $(5 \mu \mathrm{M}) \mathrm{CPS}$ - and CPS plus $(10 \mu \mathrm{M})$ CSA-treated thymocytes (>99\% $\mathrm{CD}^{+}$cells), at different times (30,60 or $120 \mathrm{~min}$ ) after treatment, was evaluated by biparametric (FSC/Annexin V-FITC) cytofluorimetric analysis. Numbers indicate the percentage of Annexin $\mathrm{V}^{+}$thymocytes. Dotted bar indicates the gates. Data are representative of three separate experiments 


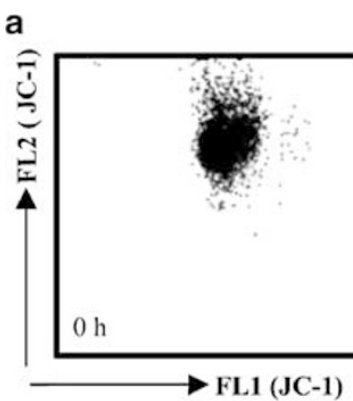

b

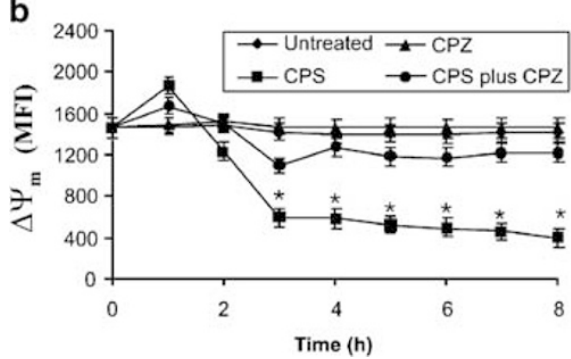

C
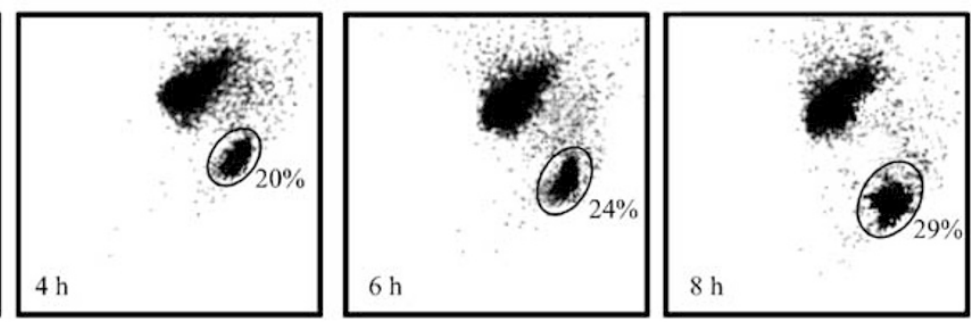

Figure 7 CPS triggers a VR1-dependent $\Delta \Psi_{\mathrm{m}}$ dissipation in rat thymocytes. (a) Time course analysis of $\Delta \Psi_{\mathrm{m}}$ changes on $(5 \mu \mathrm{M}) \mathrm{CPS}$-treated thymocytes (>99\% $\mathrm{CD}^{+}$cells) at different times (2, 4, 6 or $8 \mathrm{~h}$ ) after treatment was evaluated by biparametric FL1(green)/FL2(red) flow cytometric analysis, and JC-1 staining. Numbers indicate the percentage of gated thymocytes showing a drop in the $\Delta \Psi_{\mathrm{m}}$-related red fluorescence intensity. Data are representative of three separate experiments. (b) Time course analysis of $\Delta \Psi_{\mathrm{m}}$ changes on untreated, $(5 \mu \mathrm{M}) \mathrm{CPS},(10 \mu \mathrm{M}) \mathrm{CPZ}$ or CPS plus CPZ (1:2 agonist/antagonist ratio)-treated rat thymocytes (>99\% CD5 ${ }^{+}$ cells) at different times $(1,2,4,6$ or $8 \mathrm{~h})$ after treatment as described above. Data are representative of three separate experiments. Statistical analysis was determined by comparing untreated with CPS-treated thymocytes and CPS- with CPZ- or CPS plus CPZ-treated thymocytes; ${ }^{\star} P<0.01$ determined by Student's $t$-test. (c) The effect of CSA $(1 \mu \mathrm{M})$ or EDTA $(5 \mathrm{mM})$ on $5 \mu \mathrm{M}$ CPS-induced $\Delta \Psi_{\mathrm{m}}$ dissipation on rat thymocytes ( $>99 \% \mathrm{CD}^{+}$cells) at $4 \mathrm{~h}$ after treatment was evaluated as above described by JC-1 staining. Data, expressed as MFI of $\Delta \Psi_{\mathrm{m}}$, are the mean \pm S.D. of three different experiments. Statistical analysis was determined by comparing untreated with CPS-treated rat thymocytes and CPS- with CPS plus EDTA- or CPS plus CSA-treated thymocytes; ${ }^{\star} P<0.01$ determined by Student's $t$-test

Since we found that mitochondrial damage is essential for CPS-induced apoptotic cell death, we next examined whether cytocrome $c$ could be released from mitochondria in CPStreated thymocytes. Cytocrome $c$ release was assessed by Western blot analysis of the soluble fraction of untreated or CPS-treated thymocyte lysates using a specific anti-cytochrome $c$ monoclonal antibody $(\mathrm{mAb})$. A single immunoreactive band corresponding to a molecular mass of approximatively $12 \mathrm{kDa}$ was observed in CPS-treated thymocytes. CPS-induced traslocation of cytochrome $c$ from the mitochondria into the cell cytosol was observed $6 \mathrm{~h}$ after treatment and reached maximal levels (six-fold) at $8 \mathrm{~h}$ (Figure 8a). CPS-induced cytochrome $c$ release is mediated by VR1, as it was strongly inhibited in a time-dependent manner by CPZ (Figure 8c).

Overall, our results suggest that CPS-induced thymocyte apoptosis requires VR1-dependent cytochrome $c$ release from mitochondria.

\section{CPS treatment increases procaspase- 9 and -3 mRNA accumulation levels and activates caspase- 9 and -3 through VR1}

Mitochondrion-dependent apoptosis is initiated by recruitment and activation of caspases, ${ }^{43}$ and caspase activity is associated with vanilloid-induced apoptosis in various cell types. ${ }^{19}$ Thus, we analyzed whether caspase- 9 and -3 were activated during CPS-induced apoptosis of rat thymocytes, by monitoring the proteolysis of $46 \mathrm{kDa}$ procaspase- 9 and $32 \mathrm{kDa}$ procaspase-3 by Western blot analysis using specific Abs. CPS treatment of thymocytes stimulated the cleavage of procaspase- 9 and -3 as demonstrated by the appearance of the 37 and $17 \mathrm{kDa}$ active fragments of caspase- 9 and caspase-3 (Figure $8 \mathrm{a}$ ), respectively. Kinetics of caspase- 9 and caspase- 3 activation indicate that their activation is induced by CPS as early as active $4 \mathrm{~h}$, peaks at $6 \mathrm{~h}$ and thereafter declines. We also observed that CPS, at $6 \mathrm{~h}$ after treatment, increases (three- and two-fold) procaspase- 9 and -3 protein levels, respectively (Figure 8a), suggesting that CPS might induce procaspase-9 and -3 mRNA accumulation. Thus, we evaluated by quantitative RT-PCR whether CPS treatment enhances procaspase- 9 and -3 mRNA levels, at different times after treatment. A marked increase of procaspase-9 (about two-fold) and -3 (about three-fold) mRNA levels was observed in CPS-treated thymocytes; procaspase-9 and -3 mRNA levels were maximal after $4 \mathrm{~h}$ and decreased progressively (Figure 8b).

Finally, we demonstrated the involvement of VR1 in the CPS-induced increase of procaspase- 9 and procaspase- 3 protein levels by the use of $\mathrm{CPZ}$ antagonist. Approximatively, a five- and four-fold decrease of procaspase- 9 and procaspase-3 protein levels were detected at $6 \mathrm{~h}$ after thymocyte treatment with CPS plus CPZ (Figure 8c).

Overall, our results suggest that CPS-induced thymocyte apoptosis involves VR1-dependent increase of procaspase-9 and -3 expression and their activation. 
a
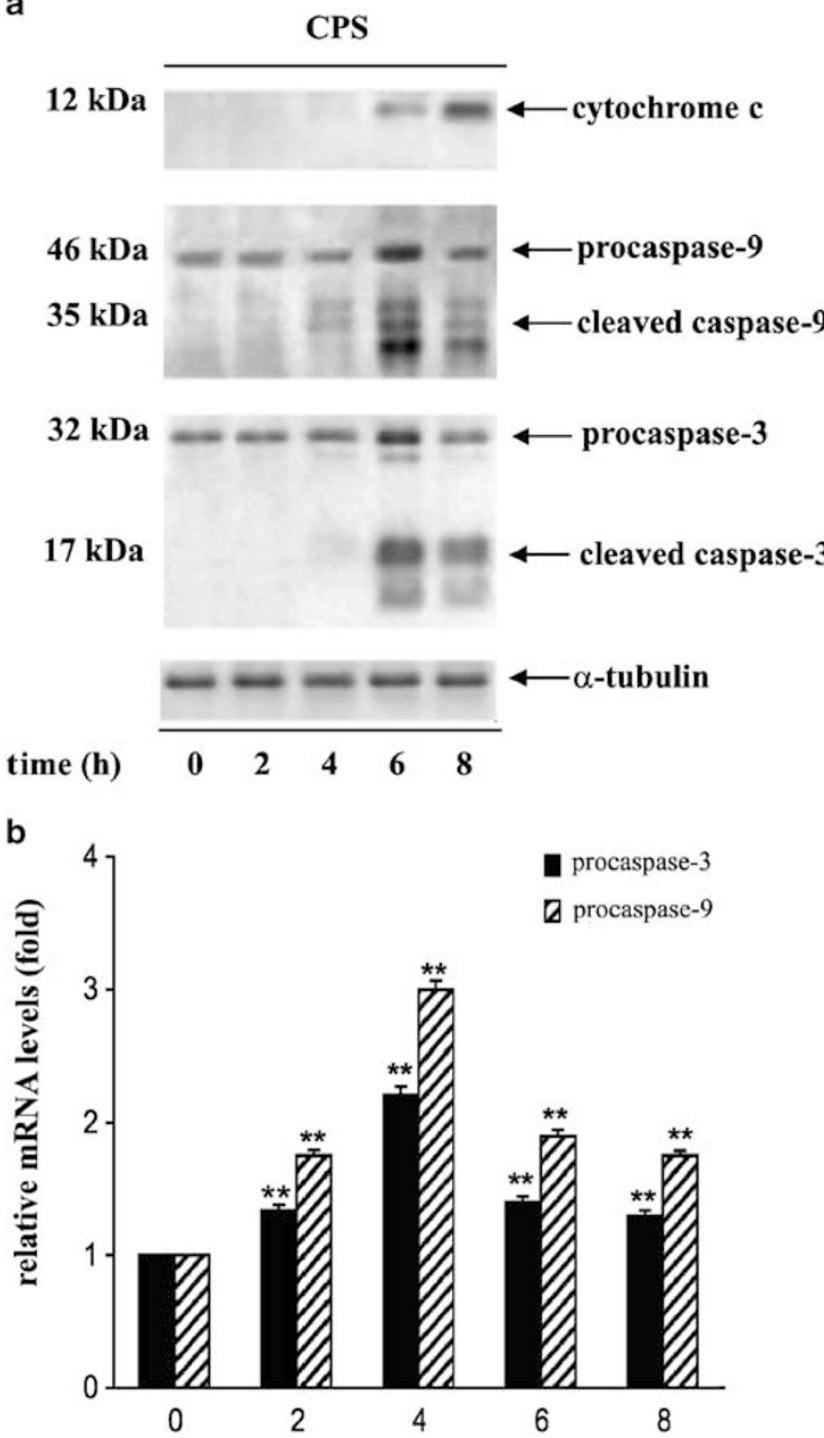

C
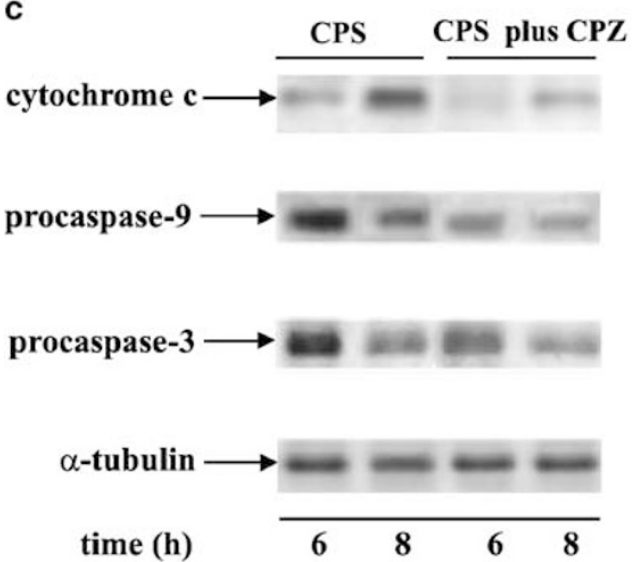

CPS induces apoptosis of CD4 ${ }^{+} \mathrm{VR1}^{+}$and double-negative (DN) VR1 ${ }^{+}$thymocyte subpopulations

Independent cell surface expression of CD4 and CD8 surface molecules define four main thymocyte subpopulations that represent different steps of thymocyte differentiation. ${ }^{44}$ Thus, we evaluated the expression of VR1 on $\mathrm{CD} 4^{+}, \mathrm{CD}^{+}$, double-positive (DP) or DN thymocyte subpopulations by immunofluorescence and cytofluorimetric analysis. VR1 was mainly expressed on DN and $\mathrm{CD} 4^{+}$thymocyte subpopulations; $\mathrm{CD} 8^{+}$thymocytes were slightly VR1 positive, and negligible VR1 expression was detected on DP cells (Figure 9a).

As DN thymocytes are a nonhomogenous cell population comprising $\mathrm{CD} 3^{\text {negative }}$ immature cells, $\mathrm{CD} 3^{\text {high }}$ mature $\mathrm{T}$ cells and $\mathrm{CD} 3^{\text {low/intermediate }}$ thymocytes that are progressing to the major DP population, ${ }^{45}$ we evaluated the expression of VR1 on CD3-positive and CD3-negative FACS-sorted DN cells. Double immunofluorescence and cytofluorimetric analysis show that all $\mathrm{CD} 3^{\text {negative }}$ immature thymocytes as well as $\mathrm{CD}^{\text {high }}$ mature T cells express high levels of VR1. Moreover, VR1 is also expressed at lower levels on the majority of thymocytes bearing intermediate levels of CD3 and on all CD ${ }^{\text {negative/low }}$ thymocytes (Figure 9b). Collectively, our results indicate that VR1 is expressed by the majority of DN cells in the thymus, although at different levels.

Based on the above results indicating that VR1 is mainly expressed on $\mathrm{DN}$ and $\mathrm{CD}^{+}{ }^{+}$thymocyte subsets, we assessed the proapoptotic ability of CPS in distinct thymocyte subsets purified by FACS. As shown by agarose gel electrophoresis (Figure 9c), CPS induced nucleosomal DNA

Figure 8 CPS induces VR1-dependent procaspase-9 and -3 expression and activation and cytochrome $c$ release from mitochondria in rat thymocytes. (a) Lysates from untreated or $5 \mu \mathrm{M}$ CPS-treated rat thymocytes at different times (2, 4,6 or $8 \mathrm{~h}$ ) after treatment were separated on SDS-PAGE and probed with mouse anti-cytochrome $c$ or anti-caspase $9 \mathrm{mAb}$, or rabbit anti-caspase 3 polyclonal $\mathrm{Ab}$. Sizes are shown in $\mathrm{kDa}$, and arrowheads indicate the bands corresponding to cytochrome $c$, procaspase-9/-3 and caspase-9/-3 cleaved fragments. Data are representative of three separate experiments. The relative cytochrome $c$ and procaspase-9/-3 levels on CPS-treated thymocytes were determined by densitometric analysis using a ChemiDoc apparatus and $\alpha$ tubulin level as loading control. Data shown are representative of one of three separate experiments. A six-fold increase in cytochrome $c$ expression was observed at $8 \mathrm{~h}$ after CPS treatment. A 3- and 1.5-fold increase in procaspase-9 expression was observed at 6 or $8 \mathrm{~h}$ after CPS treatment, respectively. A two-fold increase in procaspase- 3 expression was observed at $6 \mathrm{~h}$ after CPS treatment. (b) Procaspase- 9 and -3 mRNA levels on untreated and $5 \mu \mathrm{M}$ CPS-treated $(>99 \%$ $\mathrm{CD}^{+}$cells) thymocytes at different times $(2,4,6$ or 8$)$ after treatment were evaluated by quantitative RT-PCR in triplicate, and the results (mean + S.D.) are normalized for $\beta$ actin expression and expressed as fold increase of baseline control levels (untreated thymocytes). Data shown are representative of three separate experiments. Statistical analysis was determined as fold increase by comparing untreated with CPS-treated rat thymocytes at different times $(2,4,6$ or $8 \mathrm{~h})$ after treatment; ${ }^{*} P<0.01$ determined by Student's $t$-test. (c) Lysates from $5 \mu \mathrm{M}$ CPS- and CPS plus CPZ (1:2 agonist/antagonist ratio)-treated thymocytes, at different times ( 6 and $8 \mathrm{~h}$ ) after treatment were analyzed for the expression of cytochrome $c$, procaspase- 9 and -3 by Western blot and densitometric analysis as described in Figure 8 (panel a). A two- and three-fold decrease in cytochrome $c$ expression was observed at 6 and $8 \mathrm{~h}$ after treatment, respectively. A four- and 1.5 -fold decrease in procaspase- 9 expression was observed at 6 and $8 \mathrm{~h}$ after treatment, respectively. A 4.5- and two-fold decrease in procaspase- 3 expression was observed at 6 and $8 \mathrm{~h}$ after treatment, respectively 


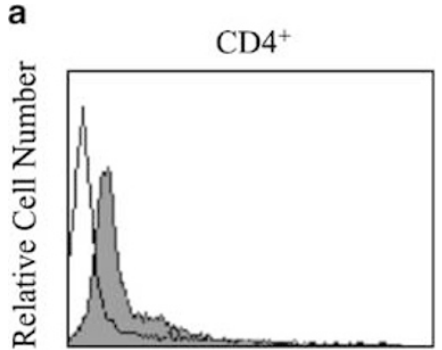

b

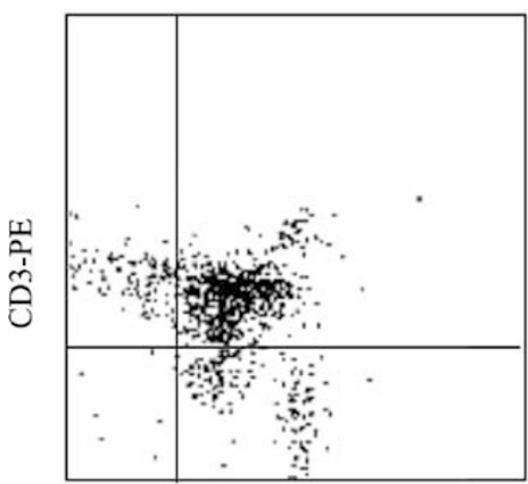

DN

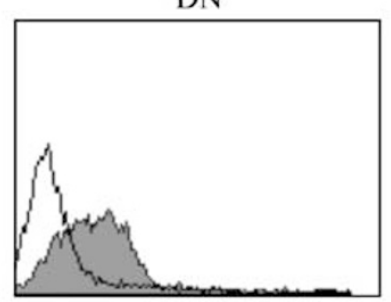

$\mathrm{CD} 8^{+}$

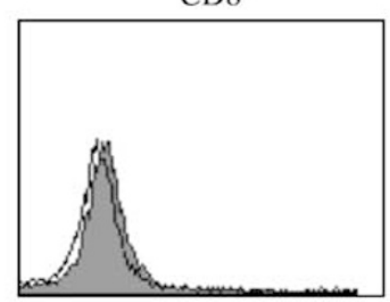

DP

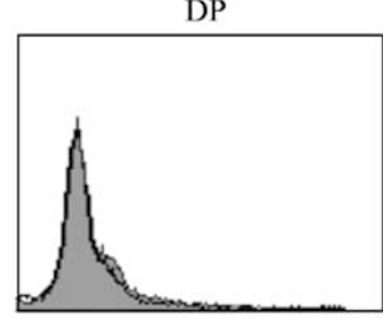

Fluorescence Intensity

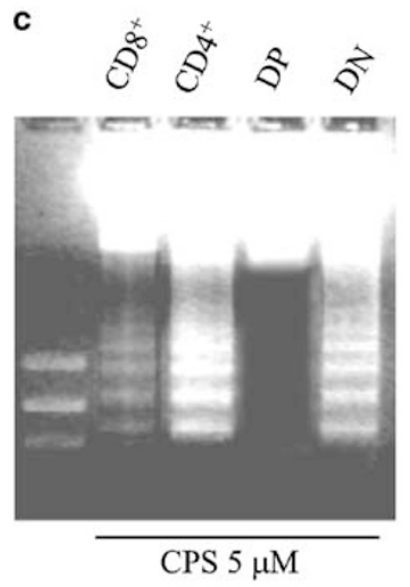

VR1-FITC

Figure 9 CPS treatment induces oligonucleosomal DNA fragmentation on distinct VR1 ${ }^{+} \mathrm{CD} 4^{+}$and DN thymocyte subsets. (a) Rat thymocytes were stained with PEconjugated anti-rat CD4 and FITC-conjugated anti-rat CD8 mAb and sorted by FACS. Sorted CD4 ${ }^{+}, \mathrm{CD} 8{ }^{+}$, DP or DN thymocytes subsets (97-99\% pure) were stained with goat anti-VR1 ( $\mathrm{NH}_{2}$ terminal peptide) polyclonal Ab followed by biotin-RAG IgG and tricolor-conjugated streptavidin and analyzed by flow cytometry. Data are representative of three separate experiments and are expressed as MFI; $\left(C D 4^{+}\right) \mathrm{RAG} \mathrm{MFI}=3.52$, anti-VR1 = 29.61; (DN) RAG MFI =5.15, anti-VR1 =26.08; $\left(\mathrm{CD}^{+}{ }^{+}\right) \mathrm{RAG} \mathrm{MFI}=10.77$, anti-VR1 = 22.09; (DP) RAG MFI = 9.40, anti-VR1 = 18.33; White areas indicate negative controls. (b) Two-color immunofluorescence was performed by staining DN-sorted permeabilized thymocytes with anti-VR1 polyclonal Ab plus FITC-conjugated RAG followed by incubation with PE-conjugated anti-rat $\mathrm{CD} 3 \mathrm{mAb}$. Data are representative of two separate experiments and are expressed as percent of positive cells; $\operatorname{CD} 3^{\text {negative }}=9.86 \%, \operatorname{CD} 3^{\text {low/negative }}=8.42 \%$, $\mathrm{CD} 3^{\text {intermediate }}=77.87 \%, \mathrm{CD} 3^{\text {high }}=3.85 \%$. (c) Oligonucleosomal DNA fragmentation from single-sorted VR1 ${ }^{+} \mathrm{CD} 4^{+}, \mathrm{VR} 1{ }^{+} \mathrm{CD} 8^{+}, \mathrm{VR} 1^{+} \mathrm{DP}, \mathrm{VR} 1{ }^{+} \mathrm{DN}, 5 \mu \mathrm{M}$ CPS-treated thymocyte subpopulations was evaluated as described above. Data are representative of two separate experiments

laddering mainly in VR1-expressing DN and CD4 ${ }^{+}$thymocytes. Less-intense nucleosomal DNA bands were observed in $\mathrm{CD}^{+}$CPS-treated thymocytes, whether the lack of VR1 expression on DP thymocytes conferred them resistance to CPS-induced apoptosis.

Overall, these results indicate that CPS promotes apoptosis of distinct subsets of rat thymocytes by interaction with VR1.

\section{Discussion}

Herein, we provide evidence on the expression of VR1 by rat thymocytes, and its involvement in their apoptotic cell death induced by in vitro treatment with CPS.

VR1 expression was evaluated on highly purified CD5 ${ }^{+}$ thymocytes, both at mRNA and protein levels. Rat VR1 mRNA was identified in $\mathrm{CD}^{+}$thymocytes by quantitative RT-PCR and quantitative analysis showed that its expression was 2.5fold lower than that observed in the cerebral cortex.

The presence of VR1 on rat thymocytes at the protein level was assessed by flow cytometry, confocal microscopy and
Western blot analysis. VR1 protein was found on a substantial portion of $\mathrm{CD}^{+}$thymocytes, mainly localized on the plasma membrane. In addition, biochemical analysis identified VR1 as a single band of $95 \mathrm{kDa}$, likely corresponding to the unglycosylated form of VR1. ${ }^{46}$

To our knowledge, these results provide the first evidence on the expression of VR1 on thymocytes both at mRNA and protein levels. These results are in agreement with recent findings showing the presence of VR1 in non-neuronal cells. $^{11-15}$

Programmed cell death is a crucial event that controls several steps of thymocyte differentiation. ${ }^{47}$

We have previously reported that neonatal CPS treatment in the rats results in a marked reduction of thymus weight and cellularity that is associated with decreased thymocyte proliferation in response to T-cell mitogens and induction of apoptotic cell death. ${ }^{6}$ However, the molecular mechanisms underlying the proapoptotic effects of CPS on rat thymus are presently unknown.

We initially evaluated the ability of CPS to induce endonuclease cleavage of DNA into oligonucleosomal size 
fragments, a biochemical hallmark of programmed cell death in many systems including thymocytes, ${ }^{48}$ by PI staining and agarose gel electrophoresis. Our results indicate that thymocyte exposure to CPS triggered two distinct pathways of cell death in a dose-dependent manner. At high concentration $(25 \mu \mathrm{M})$, necrosis is responsible for thymocyte death, whereas CPS induces apoptosis at lower concentration $(5 \mu \mathrm{M})$.

CPS-induced thymocyte apoptosis is mediated by its interaction with VR1 as it was completely inhibited by CPZ, the prototype of VR1 antagonists.

Our results also show that besides oligonucleosomal DNA degradation, CPS-induced thymocyte death fulfills other criteria of apoptosis, including $\mathrm{Ca}^{2+}$ influx, collapse of $\Delta \Psi_{\mathrm{m}}$, decrease in cell size, exposure of phosphatidylserine on the outer leaflet of the plasmamembrane, cytocrome $c$ release from mitochondria and caspase activation.

Treatment of thymocytes with CPS induced a delayed but sustained rise of $\left[\mathrm{Ca}^{2+}\right]_{\mathrm{i}}$ from 100 to $350 \mathrm{nM}$, which was completely inhibited by the permanent extracellular chelator EDTA. CPS-induced calcium flux is mediated by VR1 triggering as it was completely abrogated by the CPZ antagonist. Our results are consistent with previous evidence showing that stimulation of VR1 with low $\mu \mathrm{M}$ dose of CPS resulted in $\mathrm{Ca}^{2+}$ influx, which was inhibited by $\mathrm{CPZ}$ in a number of different neuronal and non-neuronal cell types including DRG and sensory neurons, ${ }^{27,35}$ C6 rat glioma cells, ${ }^{23}$ human epidermal keratinocytes, ${ }^{14,37}$ bone marrowderived mast cells ${ }^{15}$ and VR1 HEK293 cell transfectants. ${ }^{32}$

Calcium has been implicated in the regulation of apoptosis in several cell types. Elevation of $\mathrm{Ca}^{2+}$ following CD3 engagement, glucocorticoids and $\mathrm{Ca}^{2+}$ ionophores can induce apoptosis of thymocytes. ${ }^{38-40}$

In accordance with the role of calcium in apoptotic cell death, we observed that depletion of extracellular $\mathrm{Ca}^{2+}$ by EDTA prevented CPS-induced oligonucleosomal DNA fragmentation in rat thymocytes. Our results are in accordance with previous evidence showing the VR1-dependent stimulation of calcium by CPS in rat glioma cells. ${ }^{22}$ However, results are also available in the literature showing that CPS-induced $\left[\mathrm{Ca}^{2+}\right]_{\mathrm{i}}$ increase in human Jurkat T-cell leukemia, mitogenactivated $\mathrm{T}$ lymphocytes and glioblastoma cells is VR1independent, and uncoupled to apoptosis. ${ }^{23}$ These studies, however, have been carried out mostly in human cell types using CPS concentrations within the range responsible for the physical changes exerted by CPS on the plasma membrane. ${ }^{19,33}$

A characteristic feature of apoptotic cell death is the loss of phospholipid asymmetry and the expression of PS on the outer layer of the plasma membrane. Our results show that the CPS treatment of thymocytes rapidly induces the externalization of PS on VR1 ${ }^{+}$thymocytes, which increases in a time-dependent manner. Expression of PS on VR1 ${ }^{+}$ thymocytes is temporally associated with their depletion induced by CPS. By contrast, CPS does not induce either PS exposure nor depletion of $\mathrm{VR}^{-}$thymocytes. The involvement of VR1 on PS externalization was directly demonstrated by the ability of CPZ to revert this CPS-induced event.

Recently, mitochondria emerged as key regulator of cell death. ${ }^{49}$ Mitochondria alterations accompany apoptosis, and reduction in mitochondrial potential constitutes an early irreversible step of programmed thymocytes cell death. ${ }^{50,51}$

The current study demonstrates that CPS induces an irreversible $\Delta \Psi_{\mathrm{m}}$ dissipation, which is completely inhibited by CPZ. CPS at $5 \mu \mathrm{M}$ dose is sufficient to dissipate $\Delta \Psi_{\mathrm{m}}$, suggesting that activation of VR1 by binding to its specific ligand CPS triggers the mitochondrion-dependent apoptotic program.

We explored the role mitochondrial PTP opening in CPSinduced apoptotic cell death by the use of CSA, a mitochondrial permeability transition pore inhibitor. ${ }^{52}$ We found that CSA completely prevents CPS-induced PS exposure, in a time dependent manner, ${ }^{41}$ and block the ability of CPS to dissipate $\Delta \Psi_{\mathrm{m}}$.

Moreover, in accordance with findings of the requirement of $\left[\mathrm{Ca}^{2+}\right]_{i}$ influx in the CPS-induced DNA fragmentation, we provide evidence by the use of EDTA that $\mathrm{Ca}^{2+}$ influx plays a decisive role in the collapse of $\Delta \Psi_{m}$ upon VR1 activation by CPS, which leads to PTP opening and cell death. Similar to our results, CSA-mediated protection of murine thymocytes from loss of $\Delta \Psi_{\mathrm{m}}$ induced by $2 \mathrm{nM}$ thapsigargin has been reported. ${ }^{53}$ Interestingly, stimulation of thymocytes with $2 \mathrm{nM}$ thapsigargin induced a $\left[\mathrm{Ca}^{2+}\right]_{i}$ rise in the same range (100$250 \mathrm{nM}$ ) we observed in rat thymocytes upon CPS treatment.

The role of mitochondrial permeability transition in CPSinduced apoptosis is further supported by previous evidence indicating that overexpression of $\mathrm{Bcl}-2$ that inhibits PTP reduces CPS-induced PS exposure ${ }^{41}$ and blocks CPSmediated $\Delta \Psi_{\mathrm{m}}$ disruption and apoptosis. ${ }^{29}$

Overall, these results demonstrate that CPS-induced sustained $\left[\mathrm{Ca}^{2+}\right]_{i}$ levels are sufficient to trigger PTP opening, mitochondrial damage and apoptotic cell death in rat thymocytes.

Release of the proapoptotic factors cytochrome $c$ and AIF from mitochondria occurs during apoptosis. Cytochrome $c$ release may eventually lead to the assembly of the cytochrome $c$, ATP, Apaf-1, caspase-9 and caspase-3 complex (apoptosome), which drives activation of the caspase cascade and oligonucleosomal DNA fragmentation. ${ }^{41}$

Our results indicate that CPS induces the activation of caspase- 9 and -3 and release of cytochrome $c$ from mitochondria. Moreover, thymocyte exposure to CPS results in VR1-dependent increase of procaspase-9/-3 levels both at protein and mRNA levels, supporting the hypothesis that CPS may affect procaspase-9/-3 gene expression in these cells at transcriptional and/or post-transcriptional levels. Increased expression of procaspase- 9 and -3 may be relevant for thymocyte priming to CPS-induced apoptosis as previously suggested in neoplastic cells undergoing apoptotic cell death in response to anticancer drugs. ${ }^{54}$

Caspase activity and cytochrome $c$ release have been associated with vanilloid-induced apoptosis in various cell types. Increase in procaspase-3 cleavage was observed during CPS-induced apoptosis of human hepatocarcinoma cells, ${ }^{34}$ and increased caspase- 3 activity occurred in the CPS-induced apoptosis of $\mathrm{H}$-Ras-transformed breast epithelial cells. ${ }^{55}$ Moreover, the caspase-3 inhibitor (AcDEVD-cmk) blocked DNA fragmentation in Jurkat cells exposed to vanilloid phorbol 12-phenylacetate 13 acetate 20-homovanillate. ${ }^{56}$ 
Our results also provide evidence on the distribution of VR1 on the different thymocyte subpopulations and their susceptibility to CPS-induced apoptosis.

Double immunofluorescence and flow cytometry demonstrate that VR1 is highly expressed by the majority of $\mathrm{CD} 4^{+}$ and DN thymocytes and only marginally on $\mathrm{CD}^{+}$and $\mathrm{DP}$ cells. Expression of VR1 on DN cells is observed on both mature $C D 3^{\text {high }} \mathrm{T}$ cells as well as on $\mathrm{CD} 3^{\text {negative }}$ thymocytes and on the majority of $\mathrm{CD} 3^{\text {low/intermediate }}$ cells that are progressing into the DP population. Expression of VR1 on $\mathrm{CD}^{+}{ }^{+}$and DN thymocytes also parallels their sensitivity to CPS-induced apoptosis as evaluated by oligonucleosomal DNA degradation.

These results are in agreement with previous reports on VR1-transfected cells, indicating that VR1 expression renders these cells permissive to CPS-induced necrotic cell death. ${ }^{9,32}$ Differences in pharmacological profiles (sensitivity), regulatory mechanisms associated with vanilloid receptors or accessory multimeric subunits, receptor membrane localization, VR1 ability of forming supramolecular complexes with different receptors and signalling molecules ${ }^{10}$ among native and recombinant VR1 channels could be responsible for the differences in cell death pathways triggered by CPS through VR1 activation.

Finally, the findings of the VR1 expression on discrete subsets of $\mathrm{CD}^{+}$thymocytes supports the hypothesis that not yet identified endogenous ligand/s and/or modulators through interaction with VR1 may be involved in the regulation of thymic differentiation and functions.

To date, some endogenous VR1 ligand(s) such as palmitoyl $^{57}$ and the endocannabinoid arachidonylethanolamide (AEA, anandamide) $)^{58}$ and arachidonyl-dopamine ${ }^{59}$ have been identified.

Among these CPS-like lipids, $A E A^{58,60}$ seems to be a good candidate as physiological regulator of thymic function and differentiation as AEA has been found to modulate $T$ lymphocyte and hematopoietic cell proliferation as well as activation-induced apoptotic cell death. ${ }^{61-63}$

A role for other VR1 activators including heat $\left(43^{\circ} \mathrm{C}\right)$, protons and lipoxygenase products ${ }^{10}$ can be also envisaged. In this regard, mild hyperthermia, ${ }^{64}$ lipoxygenase products ${ }^{65}$ and cytosolic acidification ${ }^{66}$ induce DNA fragmentation and apoptosis of murine and human thymocytes. Thus, the expression of VR1 on thymocytes could endow the thymus of a sensor of harmful noxious stimuli present in the thymic microenvironment.

Overall, the potential benefits of targeting VR1 in different immune cells, and the knowledge of the molecular mechanisms controlling vanilloid-induced apoptosis could provide further support for the use of these agents in the treatment of chronic inflammatory immune-mediated diseases.

\section{Materials and Methods}

\section{Animals}

Specific pathogen-free male Wistar rats (Charles River, Calco, Italy) were used for all experiments. Rats, 10-12-week old, were housed at a constant temperature and humidity with a fixed 12-h light-dark cycle and provided with ad libitum diet of food pellet and tap water. All procedures were in accordance with the National Institutes of Health 'Guidelines for the Care and Use of Laboratory Animals'.

\section{Cell preparation}

Thymi were teased and cellular debris was removed by extensive washing. Thymocytes were isolated by centrifugation on Ficoll-Hypaque (Lymphoprep, Nycomed, Oslo, Norway) gradients, washed twice in RPMI1640 medium (Flow Laboratories, Irvine, Scotland), counted and diluted at appropriate concentrations in RPMI-1640 containing 10\% heat-inactivated fetal calf serum (FCS) (Euroclone, Devon, UK), 2 mM L-glutamine, $100 \mathrm{lU} /$ $\mathrm{ml}$ penicillin, $100 \mu \mathrm{g}$ streptomycin. Cell purity assessed by immunofluorescence and FACS analysis using anti-CD5 monoclonal antibody (mAb) was routinely $99 \%$.

\section{Antibodies and reagents}

We used the following mouse monoclonal antibodies (mAbs): phycoerythrin (PE)-conjugated and purified anti-rat CD5 (clone OX19), PE-conjugated anti-rat CD3 (clone G4.18), PE-conjugated anti-rat CD8a (clone OX8), PEconjugated or fluorescein isothiocyanate (FITC)-conjugated anti-rat CD4 (clone OX35) (Pharmingen, Palo Alto CA, USA), anti-rat cytochrome $c$ (Medical and Biological Laboratories, Nagoya City, Japan), anti-rat $\alpha$ tubulin (clone 236-10501, Molecular Probes, Eugene, OR, USA) and anti-caspase 9 (clone 96-2-22, Upstate, Waltham, MA, USA). The following affinitypurified polyclonal antibodies (Abs) were used: two affinity-purified goat anti-rat raised against the amino or carboxy terminus region of VR1 (Santa Cruz Biotechnology, Santa Cruz, CA, USA), rabbit anti-rat caspase-3 (Calbiochem-Novabiochem Corporation, San Diego, CA, USA). The horseradish peroxidase (HRP)-conjugated rabbit anti-goat (RAG), the FITC-conjugated RAG and the PE-conjugated RAG Abs were purchased from Biomeda Corporation, Foster City, CA, USA. The HRP-conjugated sheep anti-mouse and HPR-conjugated donkey anti-rabbit were from Amersham Life Sciences, Piscataway, NJ, USA. PE-mouse IgG1 and FITCmouse IgG2a (BD Biosciences) as well as goat serum (Cappel Research, Durham, NC, USA) were used as negative controls. FITC-conjugated Annexin $V$ was purchased from MedSystems, Vienna, Austria; RAG biotinylated and streptavidin-conjugated with tricolor were from Caltag Laboratories, Burlingame, CA, USA. JC-1, FDA, PI and FLUO 3-AM were obtained from Molecular Probes, Leiden, The Netherland. Capsaicin ([N(4-hydroxy-3-methoxy-phenyl)methyl]-8-methyl-6-nonenamide, CPS) and capsazepine ( $N$-[2-(4-chlorophenyl)ethyl]-1,3,4,5-tetrahydro-7,8-dihydroxy2H-2-benzazepine-2-carbothioamide, CPZ), EDTA, lonomycin, Manganese chloridrate and CSA were obtained from Sigma-Aldrich, Milano, Italy.

\section{Two-color immunofluorescence, flow cytometric analysis and cell sorting}

To determine the expression of VR1 on rat thymocytes, $1 \times 10^{6}$ cells from untreated or CPS $(5 \mu \mathrm{M})$-treated thymocytes at different times $(2,4,6$ and $8 \mathrm{~h}$ ) after treatment were fixed and permeabilized using CytoFix/CytoPerm Plus (BD Biosciences, Milano, Italy) before the addition of anti-VR1 polyclonal Abs directed against $\mathrm{NH}_{2}$ or $\mathrm{COOH}$ (data not shown) terminal peptides (1:50 dilution). Normal goat serum was used as negative control. After 30 min at $4^{\circ} \mathrm{C}$, cells were washed twice and labelled with FITCconjugated RAG (1:20 dilution). The percentage of positive cells determined over 10000 events was analyzed on a FACScan cytofluorimeter (Becton Dickinson, San Jose, CA, USA). Fluorescent intensity is expressed in arbitrary units on a logarithmic scale. Sorting of 
single-positive $\mathrm{CD} 4^{+}$and $\mathrm{CD} 8^{+}$, double-positive (DP) $\mathrm{CD} 4^{+} \mathrm{CD} 8^{+}$and double-negative (DN) $\mathrm{CD}^{-} \mathrm{CD}^{-}$thymocytes was performed on FACStar-Plus cell sorter (Becton Dickinson) equipped with an Enterprise laser emitting $150 \mathrm{~mW}$ at $488 \mathrm{~nm}$. In all, $1 \times 10^{8}$ thymocytes, previously labelled with FITC-conjugated anti-CD4 and PE-conjugated anti-CD8 mAbs (1:50 dilution), underwent two rounds of sorting by gating on fluorescence-triggered cells using the FACStar-Plus software. Purity of sorted thymocytes was around $97-99 \%$ as analyzed with CellQuest software (data not shown). Single-sorted thymocyte subpopulations were then permeabilized and stained with anti-VR1 antiserum, followed by biotin-conjugated RAG IgG (1:50 dilution) and tricolor-conjugated streptavidin (Caltag Laboratories, Burlingame, CA, USA). Electronic compensation was used between green and orange, and orange and red fluorescences to remove spectral overlap. Two-color immunofluorescence was performed by staining DN-sorted permeabilized thymocytes with antiVR1 polyclonal Ab plus FITC-conjugated RAG followed by incubation with $\mathrm{PE}$-conjugated anti-rat CD3 $\mathrm{mAb}$. The cytofluorimetric analysis was performed on a FACSCalibur using CELLQuest software (Becton Dickinson).

\section{Confocal laser scanning microscopy analysis}

Thymocytes permeabilized as described above were incubated with goat anti-VR1 $\left(\mathrm{NH}_{2}\right.$ terminus) polyclonal $\mathrm{Ab}(1: 50)$ for $1 \mathrm{~h}$ at $4^{\circ} \mathrm{C}$. Samples were then incubated with FITC-conjugated RAG Ab $(1: 100)$ for $1 \mathrm{~h}$ at $4^{\circ} \mathrm{C}$, washed, mounted on slides and finally analyzed with MRC600 confocal laser scanning microscope (BioRad, Hercules, CA, USA) equipped with a Nikon (Diaphot-TMD) inverted microscope. Fluorochrome was excited with the 600 line of an argon-kripton laser and imaged using a 488 (FITC)$\mathrm{nm}$ bandpass filter. Serial optical sections were taken at $1-\mu \mathrm{m}$ intervals through the cells. Images were processed using Jacs Paint Shop Pro (Jacs Sotfware Inc.).

\section{Staining with FDA, PI and Annexin V}

Thymocytes, untreated or treated for $8 \mathrm{~h}$ with CPS at different doses $(5,10$ or $25 \mu \mathrm{M}$ ) at $37^{\circ} \mathrm{C}, 5 \% \mathrm{CO}_{2}$, were incubated for $5 \mathrm{~min}$ at $37^{\circ} \mathrm{C}$ with $0.125 \mu \mathrm{g} / \mu \mathrm{lFDA}$, an agent that is metabolized to fluorescein in living cells, or $0.2 \mu \mathrm{g} \mathrm{PI}$ in $0.2 \mathrm{ml}$ of binding buffer, ${ }^{67}$ respectively. After washing in phosphate-buffered saline (PBS), samples were analyzed on a FACScan cytofluorimeter using the CellQuest software.

Phosphatidylserine (PS) exposure on VR1 thymocytes was detected by Annexin V staining and cytofluorimetric analysis. Briefly, $1 \times 10^{6}$ thymocytes, untreated or treated with CPS $(5 \mu \mathrm{M}), \mathrm{CPZ}(10 \mu \mathrm{M})$, alone or in combination (1:2 agonist/antagonist ratio) at different times (2, 4, 6 or $8 \mathrm{~h}$ ), were fixed, permeabilized and stained with anti-VR1 polyclonal $\mathrm{Ab}$ as described above. After $30 \mathrm{~min}$ at $4^{\circ} \mathrm{C}$, cells were washed, labelled with PE-conjugated RAG (1:20 dilution), and incubated with $5 \mu$ l Annexin VFITC for $10 \mathrm{~min}$ at room temperature. The involvement of mitochondrial PTP in CPS-induced PS externalization was evaluated on thymocytes treated for different times $(30,60$ or $120 \mathrm{~min})$ with $5 \mu \mathrm{M}$ CPS in the presence of $1 \mu \mathrm{M} \mathrm{CSA}$, by Annexin V-FITC staining and flow cytometric analysis as described above.

\section{$\left[\mathrm{Ca}^{2+}\right]_{\mathrm{i}}$ measurement}

Intracellular $\mathrm{Ca}^{2+}$ flux was measured as described ${ }^{68}$ with some modifications. Briefly, $1 \times 10^{7} / \mathrm{ml}$ thymocytes were washed in RPMl1640 supplemented with 1\% FCS (RPMI/FCS medium). The cells were resuspended with RPMI/FCS medium supplemented with $7 \mu \mathrm{M}$ FLUO
3-AM and $1 \mu \mathrm{g} / \mathrm{ml}$ Pluronic F-127 (Molecular Probes), dissolved in dimethylsulfoxide (DMSO), and incubated in the dark for $45 \mathrm{~min}$ at $37^{\circ} \mathrm{C}$, $5 \% \mathrm{CO}_{2}$. After washing, cells were resuspended in RPMI/FCS medium supplemented or not with $5 \mathrm{mM}$ EDTA, warmed to $37^{\circ} \mathrm{C}$ for $5 \mathrm{~min}$, and stimulated with $5 \mu \mathrm{M}$ of CPS for different times. FLUO-3 fluorescence was measured on the flow cytometer at $525 \mathrm{~nm}$ on the green channel; unstimulated cells were analyzed for $2 \mathrm{~min}$ to establish baseline fluorescence levels.

$\Delta \Psi_{\mathrm{m}}$

The $\Delta \Psi_{\mathrm{m}}$ was evaluated by JC-1 staining. JC-1 is a membrane potentialsensitive probe that accumulates in energized mitochondria and subsequently forms J-aggregate from monomers. Drop of $\Delta \Psi_{m}$ decreases the J-aggregate emission at $590 \mathrm{~nm}$ (red fluorescence) and increases the monomer emission at $530 \mathrm{~nm}$ (green fluorescence). ${ }^{42}$ Briefly, $1 \times 10^{6}$ cells resuspended in RPMI/FCS supplemented or not with $5 \mathrm{mM}$ EDTA, treated with $5 \mu \mathrm{M}$ of CPS, alone or in combination with $\mathrm{CPZ}$ (1:2 agonist/antagonist ratio), for different times $(0,2,4,6$ or $8 \mathrm{~h})$ at $37^{\circ} \mathrm{C}$ in $5 \% \mathrm{CO}_{2}$ were incubated for $10 \mathrm{~min}$ at room temperature with $300 \mu \mathrm{l}$ of $10 \mu \mathrm{g} / \mathrm{ml} \mathrm{JC}-1$ and analyzed by a FACscan cytofluorimeter (Becton Dickinson). In some experiments, thymocytes were treated with $5 \mu \mathrm{M}$ CPS in the presence of $1 \mu \mathrm{M}$ CSA. JC-1 was excited by an argon laser $(488 \mathrm{~nm})$ and green $(530 \mathrm{~nm}) / \mathrm{red}(>570 \mathrm{~nm})$ emission fluorescence was collected simultaneously. Data were analyzed using the Cell Quest software.

\section{Assessment of DNA fragmentation}

Dose-response and time-course experiments of CPS-induced nucleosomal DNA fragmentation were performed by agarose gel electrophoresis. Briefly, $5 \times 10^{5} / \mathrm{ml}$ thymocytes were cultured at $37^{\circ} \mathrm{C}, 5 \% \mathrm{CO}_{2}$ with different doses of CPS $(5,10$ or $25 \mu \mathrm{M})$ for $8 \mathrm{~h}$ or with $5 \mu \mathrm{M}$ CPS for different times $(2,4,6$ or $8 \mathrm{~h})$. After treatment, cells were washed and DNA was extracted using the Genomix Cells and Tissues Mini Preparations kit (Talent, Trieste, Italy). The DNA samples were electrophoresed on a 1.7\% agarose gel and stained with ethidium bromide and acquired by a ChemiDoc (BioRad, Milano, Italy). In some experiments, $5 \mu \mathrm{M}$ CPStreated thymocytes were treated with $10 \mu \mathrm{M} \mathrm{CPZ}$ or $5 \mathrm{mM}$ of EDTA. DNA fragmentation was also analysed in single-sorted CPS-treated thymocytes subpopulations.

\section{Western blot analysis}

Lysates obtained from rat thymocytes and cerebral cortex used as positive control $^{7}$ were resuspended in $0.2 \mathrm{ml}$ of RIPA $(0.1 \%$ Nonidet-P $40,1 \mathrm{mM}$ $\mathrm{CaCl}_{2}, 1 \mathrm{mM} \mathrm{MgCl}_{2}, 0.1 \%$ sodium azide, $1 \mathrm{mM} \mathrm{PMSF}$ (phenylmethylsulfonylfluoride), $0.03 \mathrm{mg} / \mathrm{ml}$ aprotinin, $1 \mathrm{mM} \mathrm{NaVO}$ ). Samples were separated on 7\% SDS-polyacrylamide gel, transferred onto Immobilon-P membranes (Millipore, Bedford, MA, USA), and blotted with goat anti-VR1, $\mathrm{NH}_{2}$ terminal peptide $(1: 400)$ polyclonal Ab followed by the incubation with HRP-conjugated RAG $(1: 20000)$ Ab. Similar results were obtained using a polyclonal $\mathrm{Ab}$ directed against the VR1 $\mathrm{COOH}$ terminal peptide $(1: 400)$ (data not shown). In some experiments, thymocytes were treated for 2, 4, 6 and $8 \mathrm{~h}$ at $37^{\circ} \mathrm{C}, 5 \% \mathrm{CO}_{2}$ with $\mathrm{CPS}(5 \mu \mathrm{M})$ alone or in combination with CPZ (1:2 agonist/antagonist ratio), and lysed as described above. Proteins were separated on 10 and $14 \%$ SDSpolyacrylamide gels, for caspase- 9 and caspase-3, respectively, transferred overnight at $20 \mathrm{~V}$, and incubated for $2 \mathrm{~h}$ at room temperature with either a mouse anti-caspase $9 \mathrm{mAb}$ followed by HPR-conjugated anti- 
mouse $\mathrm{Ab}(1: 10000)$, or with a rabbit anti-caspase $3 \mathrm{Ab}(1: 500)$ followed by an HPR-conjugated anti-rabbit $(1: 10000) \mathrm{Ab}$.

In addition, to evaluate cytochrome $c$ release, untreated or CPS-treated thymocytes were washed in ice-cold PBS and the resulting pellet was resuspended in $0.2 \mathrm{ml}$ of lysis buffer $(20 \mathrm{mM}$ Hepes, $10 \mathrm{mM} \mathrm{KCl}, 1.5 \mathrm{mM}$ $\mathrm{MgCl}_{2}, 1 \mathrm{mM}$ EDTA, $1 \mathrm{mM}$ EGTA, $1 \mathrm{mM}$ dithiothreitol and $0.1 \mathrm{mM}$ PMSF) supplemented with protease inhibitors $(5 \mu \mathrm{g} / \mathrm{ml}$ pepstatin $A, 10 \mu \mathrm{g} / \mathrm{ml}$ leupeptin and $2 \mu \mathrm{g} / \mathrm{ml}$ aprotinin). After sitting on ice for $15 \mathrm{~min}$, cells were disrupted by 60 times douncing in a mini-potter. The nuclei were pelletted at $1000 \times g$ for $5 \mathrm{~min}$ at $4{ }^{\circ} \mathrm{C}$ and the supernatants were separated and centrifuged for $40 \mathrm{~min}$ at $80000 \times \mathrm{g}$. Then, supernatants loaded onto a $14 \%$ SDS-polyacrylamide gel were transferred overnight at $20 \mathrm{~V}$, and incubated with anti-cytochrome $c \mathrm{mAb}(0.5 \mu \mathrm{g} / \mathrm{ml})$ for $2 \mathrm{~h}$, followed by HPR-conjugated anti-mouse $(1: 10000) \mathrm{Ab}$. Immunoreactivity was detected using the Enhanced Chemiluminescence (ECL, Amersham). Densitometric analysis was performed by a Chemidoc using the Quantity One software (BioRad). Each sample was compared to its control ( $\alpha$ tubulin) for the purpose of quantification.

\section{RNA isolation and reverse transcription}

Messenger RNA was extracted from untreated Ficoll-purified thymocytes, CPS-treated thymocytes at different times (2, 4, 6 and $8 \mathrm{~h}$ ) after treatment or cerebral cortex used as positive control, ${ }^{16}$ using the Quick Messenger RNA Direct kit (Talent, Trieste, Italy). The mRNA samples were resuspended in diethylpyrocarbonate (DEPC) (Sigma, Milano, Italy) water and their concentration and purity were evaluated by $A_{260}$ measurement. mRNA samples (200 ng) were subjected to reverse transcription using the High Capacity cDNA Archive Kit protocol (RT buffer, dNTP mixture, Random Primers, MultiScribe RT, RNase inhibitor, Applied Biosystems, Monza, Italy). In all, $2 \mu$ l of the resulting cDNA products were used as template for RT-PCR quantification.

\section{Quantitative RT-PCR analysis}

Quantitative RT-PCR was performed using a GeneAmp 5700 Sequence Detection System (Applied Biosystems, Monza, Italy). The reaction mixture contained the Taqman Universal PCR Master Mix (Applied Biosystems) and Taqman primer and probe sets. Taqman forward and reverse primers and probe sets were designed from sequences in the GeneBank database by Primer Express software (Applied Biosystems):

VR1: 5'-GGACACTATGCAGGGATCAATG， 5'-GAGTGGACCCAGA TAACGTCAAC, 5'-CTTTGGGTGGTCTGCTTAGGGAACCAG;

Procaspase-9: 5'-CTGAGCCCAGGAGTTGACTGA, 5'-CCCACTAG GGTAACCAACAGACA, 5'-AGCCAGAGTCCCCACTGATCAAGTC;

Procaspase-3: 5'-AATTCAAGGGACGGGTCATG, 5'-GCTTGTGCGC GTACAGTTTC, 5'-TTCATCCAGTCACTTTGCGCCATGC;

GAPDH (glyceraldehyde-3-phosphate dehydrogenase): $5^{\prime}$-CGGATTG GCCGTATTGG, 5'-CAATGTCCACTTTGTCACAAGAGAA, 5'-CGCCTG GTCACCAGGGCTG.

$\beta$ actin: 5'-CCCAGCCATGTACGTTGCTA, 5'-TCACCGGAGTCCAT CACGAT, 5'-ACGCCTCTGGCCGTACCACTGG

Each PCR amplification consists of heat activation for $2 \mathrm{~min}$ at $50^{\circ} \mathrm{C}$, and for $10 \mathrm{~min}$ at $95^{\circ} \mathrm{C}$, followed by 45 cycles of $94^{\circ} \mathrm{C}$ for $20 \mathrm{~s}, 55^{\circ} \mathrm{C}$ for $20 \mathrm{~s}$ and $72^{\circ} \mathrm{C}$ for $30 \mathrm{~s}$.

All controls and samples were assayed in triplicate in the same plate. Measurement of glyceraldehyde-3-phosphate dehydrogenase (GAPDH) mRNA or $\beta$ actin levels on the samples, performed in the same plate, was used as control to normalize mRNA contents. VR1 and procaspase- 9 and
-3 mRNA levels were expressed as relative fold of the corresponding control as indicated in the figure legends. Statistical analysis was carried out on all the Taqman PCR data. PCR products were also analyzed by electrophoresis on $2 \%$ ethidium bromide-stained agarose gel, visualized by UV transilluminator and acquired by a Chemi Doc (BioRad).

\section{Statistical analysis}

The statistical significance was determined by Student's $t$-test at $P<0.01$.

\section{Acknowledgements}

This study was partially supported by Ministero dell'Università e della Ricerca Scientifica e Tecnologica (MIUR), University of Camerino.

\section{References}

1. Holzer P (1991) Capsaicin: cellular targets, mechanism of action, and selectivity for thin sensory neurones. Pharmacol. Rev. 43: 143-201

2. Santoni G, Perfumi M, Birarelli P, Procaccini S and Piccoli M (1995) In vivo capsaicin treatment inhibits rat NK cell cytotoxic functions. Immunopharmacol. Immunotoxicol. 17: 511-528

3. Santoni G, Perfumi M, Bressan AM and Piccoli M (1996) Capsaicin-induced inhibition of mitogen and interleukin-2-stimulated $T$ cell proliferation: its reversal by in vivo substance $P$ administration. J. Neuroimmunol. 68: 131-138

4. Santoni G, Perfumi MC, Pompei P, Spreghini E, Lucciarini R, Martarelli D, Staffolani M and Piccoli M (2000) Impairment of rat thymocyte differentiation and functions by neonatal capsaicin treatment is associated with induction of apoptosis. J. Neuroimmunol. 104: 37-46

5. Santoni G, Perfumi MC, Spreghini E, Romagnoli S and Piccoli M (1999) Neurokinin type-1 receptor antagonist inhibits enhancement of $T$ cell functions by substance $P$ in normal and neuromanipulated capsaicin-treated rats. J. Neuroimmunol. 93: 15-25

6. Santoni G, Amantini C, Lucciarini R, Perfumi M, Pompei P and Piccoli M (2004) Neonatal capsaicin treatment affects rat thymocyte proliferation and cell death by modulating substance $P$ and neurokinin-1 receptor expression. Neuroimmunomodulation 11: 160-172

7. Szallasi A and Blumberg PM (1999) Vanilloid (capsaicin) receptors and mechanisms. Pharmacol. Rev. 51: 159-211

8. Caterina MJ and Julius D (2001) The vanilloid receptor: a molecular gateway to the pain pathway. Annu. Rev. Neurosci. 24: 487-517

9. Caterina MJ, Schumacher MA, Tominaga M, Rosen TA, Levine JD and Julius D (1997) The capsaicin receptor: a heat-activated ion channel in the pain pathway. Nature 389: 816-824

10. Gunthorpe MJ, Benham CD, Randall A and Davis JB (2002) The diversity in the vanilloid (TRPV) receptor family of ion channels. Trends Pharmacol. Sci. 23 : 183-191

11. Birder LA, Kanai AJ, de Groat WC, Kiss S, Nealen ML, Burke NE, Dineley KE, Watkins S, Reynolds IJ and Caterina MJ (2001) Vanilloid receptor expression suggests a sensory role for urinary bladder epithelial cells. Proc. Natl. Acad. Sci. USA 98: 13396-13401

12. Dvorakova M and Kummer W (2001) Transient expression of vanilloid receptor subtype 1 in rat cardiomyocytes during development. Histochem. Cell Biol. 116: 223-225

13. Kato S, Aihara E, Nakamura A, Xin H, Matsui $\mathrm{H}$, Kohama $\mathrm{K}$ and Takeuchi $\mathrm{K}$ (2003) Expression of vanilloid receptors in rat gastric epithelial cells: role in cellular protection. Biochem. Pharmacol. 66: 1115-1121

14. Southall MD, Li T, Gharibova LS, Pei Y, Nicol GD and Travers JB (2003) Activation of epidermal vanilloid receptor-1 induces release of proinflammatory mediators in human keratinocytes. J. Pharmacol. Exp. Ther. 304: 217-222

15. Biro T, Maurer M, Modarres S, Lewin NE, Brodie C, Acs G, Acs P, Paus R and Blumberg PM (1998) Characterization of functional vanilloid receptors expressed by mast cells. Blood 91: 1332-1340 
16. Schumacher MA, Moff I, Sudanagunta SP and Levine JD (2000) Molecular cloning of an $\mathrm{N}$-terminal splice variant of the capsaicin receptor. Loss of $\mathrm{N}$ terminal domain suggests functional divergence among capsaicin receptor subtypes. J. Biol. Chem. 275: 2756-2762

17. Clapham DE (1997) Some like it hot: spicing up ion channels. Nature 389 783-784

18. Caterina MJ, Leffler A, Malmberg AB, Martin WJ, Trafton J, Petersen-Zeitz KR, Koltzemburg M, Basbaum Al and Julius D (2000) Impaired nociception and pain sensation in mice lacking the capsaicin receptor. Science 288: 306-313

19. Hail Jr N (2003) Mechanisms of vanilloid-induced apoptosis. Apoptosis 8: 251-262

20. Morre DJ, Chueh PJ and Morrè DM (1995) Capsaicin inhibits preferentially the NADH oxidase and growth of transformed cells in culture. Proc. Natl. Acad. Sci. USA 92: 1831-1835

21. Wolvetang EJ, Larm JA, Moutsoulas P and Lawen A (1996) Apoptosis induced by inhibitors of the plasma membrane $\mathrm{NADH}$-oxidase involves $\mathrm{Bcl}-2$ and calcineurin. Cell Growth Differ. 7: 1315-1325

22. Biro $T$, Brodie $C$, Modarres $S$, Lewin NE, Acs $P$ and Blumberg $P M$ (1998) Specific vanilloid responses in C6 rat glioma cells. Brain Res. Mol. 56: 89-98

23. Macho A, Calzado MA, Munoz-Blanco J, Gomez-Diaz C, Gajate C, Mollinedo $F$, Navas $P$ and Munoz $E$ (1999) Selective induction of apoptosis by capsaicin in transformed cells: the role of reactive oxygen species and calcium. Cell Death Differ. 6: 155-165

24. Jambrina $E$, Alonso $R$, Alcalde $M$, del Carmen Rodriguez $M$, Serrano A, Martinez-A C, Garcia-Sancho J and Izquierdo M (2003) Calcium influx through receptor-operated channel induces mitochondria-triggered paraptotic cell death. J. Biol. Chem. 278: 14134-14145

25. Zhang J, Nagasaki M, Tanaka Y and Morikawa S (2003) Capsaicin inhibits growth of adult T-cell leukemia cells. Leuk. Res. 27: 275-283

26. Sugimoto $T$, Xiao $C$ and Ichikawa $H$ (1998) Neonatal primary neuronal death induced by capsaicin and axotomy involves an apoptotic mechanism. Brain Res. 807: 147-154

27. Dedov VN, Mandadi S, Armati PJ and Verkhratsky A (2001) Capsaicin-induced depolarisation of mitochondria in dorsal root ganglion neurons is enhanced by vanilloid receptors. Neuroscience 103: 219-226

28. Lee YS, Nam DH and Kim JA (2000) Induction of apoptosis by capsaicin in A172 human glioblastoma cells. Cancer Lett. 161: 121-130

29. Macho A, Blazquez MV, Navas P and Munoz E (1998) Induction of apoptosis by vanilloid compounds does not require de novo gene transcription and activator protein 1 activity. Cell Growth Differ. 9: 277-286

30. Hiura A, Nakae $\mathrm{Y}$ and Nakagawa $\mathrm{H}$ (2002) Cell death of primary afferent nerve cells in neonatal mice treated with capsaicin. Anat. Sci. Int. 77: 47-50

31. Olah Z, Karai L and ladarola MJ (2001) Anandamide activates vanilloid receptor 1 (VR1) at acidic $\mathrm{pH}$ in dorsal root ganglia neurons and cells ectopically expressing VR1. J. Biol. Chem. 276: 31163-31170

32. Grant ER, Dubin AE, Zhang SP, Zivin RA and Zhong Z (2002) Simultaneous intracellular calcium and sodium flux imaging in human vanilloid receptor 1 (VR1)-transfected human embryonic kidney cells: a method to resolve ionic dependence of VR1-mediated cell death. J. Pharmacol. Exp. Ther. 300: 9-17

33. Meddings JB, Hogaboam CM, Tran K, Reynolds JD and Wallace JL (1991) Capsaicin effects on non-neuronal plasma membranes. Biochem. Biophys. Acta 1070: 43-50

34. Jung MY, Kang HJ and Moon A (2001) Capsaicin-induced apoptosis in SKHep-1 hepatocarcinoma cells involves Bcl-2 downregulation and caspase-3 activation. Cancer Lett. 165: 139-145

35. Bevan S, Hothi S, Hughes G, James IF, Rang HP, Shah K, Walpole CS and Yeats JC (1992) Capsazepine: a competitive antagonist of the sensory neurone excitant capsaicin. Br. J. Pharmacol. 107: 544-552

36. Wood JN, Winter J, James IF, Rang HP, Yeats J and Bevan S (1988) Capsaicin-induced ion fluxes in dorsal root ganglion cells in culture. J. Neurosci. 8: 3208-3220

37. Inoue K, Koizumi S, Fuziwara S, Denda S, Inoue K and Denda M (2002) Functional vanilloid receptors in cultured normal human epidermal keratinocytes. Biochem. Biophys. Res. Commun. 291: 124-129

38. McConkey DJ and Orrenius S (1997) The role of calcium in the regulation of apoptosis. Biochem. Biophys. Res. Commun. 239: 357-366
39. McConkey DJ, Hartzell P, Jondal M and Orrenius S (1989) Inhibition of DNA fragmentation in thymocytes and isolated thymocyte nuclei by agents that stimulate protein kinase C. J. Biol. Chem. 264: 13399-13402

40. McConkey DJ, Hartzell P, Amador-Perez JF, Orrenius S and Jondal M (1989) Calcium-dependent killing of immature thymocytes by stimulation via the $\mathrm{CD} 3 / \mathrm{T}$ cell receptor-complex. J. Immunol. 143: 1801-1806

41. Kroemer $G$ and Reed JC (2000) Mitochondrial control of cell death. Nat. Med. 6: 513-519

42. Nicoletti I, Migliorati G, Pagliacci MC, Grignani F and Riccardi C (1991) A rapid and simple method for measuring thymocyte apoptosis by propidium iodide staining and flow cytometry. J. Immunol. Methods 139: 271-279

43. Cohen GM (1997) Caspases: the executioners of apoptosis. Biochem. J. 326: 1-15

44. Scollay R and Shortman K (1983) Thymocyte subpopulations: an experimental review including flow cytometric cross-correlation between the major murine thymocyte markers. Thymus 5: 245-249

45. Hunig T, Torres-Nagel N, Mehling B, Park HJ and Herrmann T (2001) Thymic development and repertoire selection, the rat perspective. Immunol. Rev. 184: 7-19

46. Kedei N, Szabo T, Lile JD, Treanor JJ, Olah Z, ladarola MJ and Blumberg PM (2001) Analysis of the native quaternary structure of vanilloid receptor 1 . J. Biol. Chem. 276: 28613-28619

47. Osborne BA (1996) Apoptosis and maintenance of homeostasis in the immune system. Curr. Opin. Immunol. 8: 245-254

48. Quaglino D and Ronchetti IP (2001) Cell death in the rat thymus: a minireview. Apoptosis 6: $389-401$

49. Mignotte B and Vayssiere JL (1998) Mitochondria and apoptosis. Eur. J. Biochem. 252: 1-15

50. Zamzami N, Marchetti P, Castedo M, Zanin C, Vayssiere JL, Petit PX and Kroemer G (1995) Reduction in mitochondrial potential constitutes an early irreversible step of programmed lymphocyte death in vivo. J. Exp. Med. 181: 1661-1672

51. Kroemer G, Zamzami N and Susin SA (1997) Mitochondrial control of apoptosis. Immunol. Today 18: 44-51

52. Andreyev A and Fiskum G (1999) Calcium induced release of mitochondrial cytochrome $c$ by different mechanisms selective for brain versus liver. Cell Death Differ. 6: 825-832

53. Waring $P$ and Beaver $J$ (1996) Cyclosporin A rescues thymocytes from apoptosis induced by very low concentrations of thapsigargin: effects on mitochondrial function. Exp. Cell Res. 227: 264-276

54. Micheau O, Hammann A, Solary E and Dimanche-Boitrel MT (1999) STAT-1Indipendent upregulation of FADD and procaspase-3 and -8 in cancer cells treated with cytotoxic drugs. Biochem. Biophys. Res. Commun. 256: 603-607

55. Kang HJ, Soh Y, Kim MS, Lee EJ, Surh YJ, Kim HR, Kim SH and Moon A (2003) Roles of JNK-1 and p38 in selective induction of apoptosis by capsaicin in ras-transformed human breast epithelial cells. Int. J. Cancer. 103: 475-482

56. Macho A, Lucena C, Calzado MA, Blanco M, Donnay I, Appendino G and Munoz E (2000) Phorboid-20-homovanillates induces apoptosis through a VR1-independent mechanism. Chem. Biol. 7: 277-286

57. De Petrocellis L, Bisogno T, Ligresti A, Bifulco M, Melck D and Di Marzo V (2002) Effect on cancer cell proliferation of palmitoylethanolamide, a fatty acid amide interacting with both the cannabinoid and vanilloid signalling systems. Fundam. Clin. Pharmacol. 16: 297-302

58. Ross RA (2003) Anandamide and vanilloid TRVP1 receptors. Br. J. Pharmacol. 140: $790-801$

59. Hwang SW, Cho H, Kwak J, Lee SY, Kang CJ, Jung J, Cho S, Min KH, Suh YG, Kim D and Oh U (2000) Direct activation of capsaicin receptors by products of lipoxygenases: endogenous capsaicin-like substances. Proc. Natl. Acad. Sci. USA 97: 6155-6160

60. Zygmunt PM, Petersson J, Andersson DA, Chuang H, Sorgard M, Di Marzo V, Julius D and Hogestatt ED (1999) Vanilloid receptors on sensory nerves mediate the vasodilator action of anandamide. Nature 400: 452-457

61. Schwarz H, Blanco FJ and Lotz M (1994) Anandamide, an endocannabinoid receptor agonist inhibits lymphocyte proliferation and induces apoptosis. J. Neuroimmunol. 55: 107-115

62. Valk P, Verbakel S, Vankan Y, Hol S, Mancham S, Ploemacher R, Mayen A, Lowenberg B and Delwel R (1997) Anandamide, a natural ligand for the peripheral cannabinoid receptor is a novel synergistic growth factor for hematopoietic cells. Blood 90: 1448-1457 
63. Maccarrone $M$, Lorenzon $T$, Bari $M$, Melino $G$ and Finazzi-Agro A (2000) Anandamide induces apoptosis in human cells via vanilloid receptors. Evidence for a protective role of cannabinoid receptors. J. Biol. Chem. 275: 31938-31945

64. Sellins KS and Cohen JJ (1991) Hyperthermia induces apoptosis in thymocytes. Radiat. Res. 126: 88-95

65. Maccarone M, Melino G and Finazzi-Agro A (2001) Lipoxygenases and their involvement in programmed cell death. Cell Death Differ. 8: 776-784
66. Frey T (1997) Correlated flow cytometric analysis of terminal events in apoptosis reveals the absence of some changes in some model systems. Cytometry 28: 253-263

67. Sandstrom K, Hakansson L, Lukinius A and Venge P (2000) A method to study apoptosis in eosinophils by flow cytometry. J. Immunol. Methods 240: 55-68

68. Kao JPY, Harootunian AT and Tsein RY (1989) Photochemically generated cytosolic calcium pulses and their detection by Fluo 3. J. Biol. Chem. 264: 8179-8184 